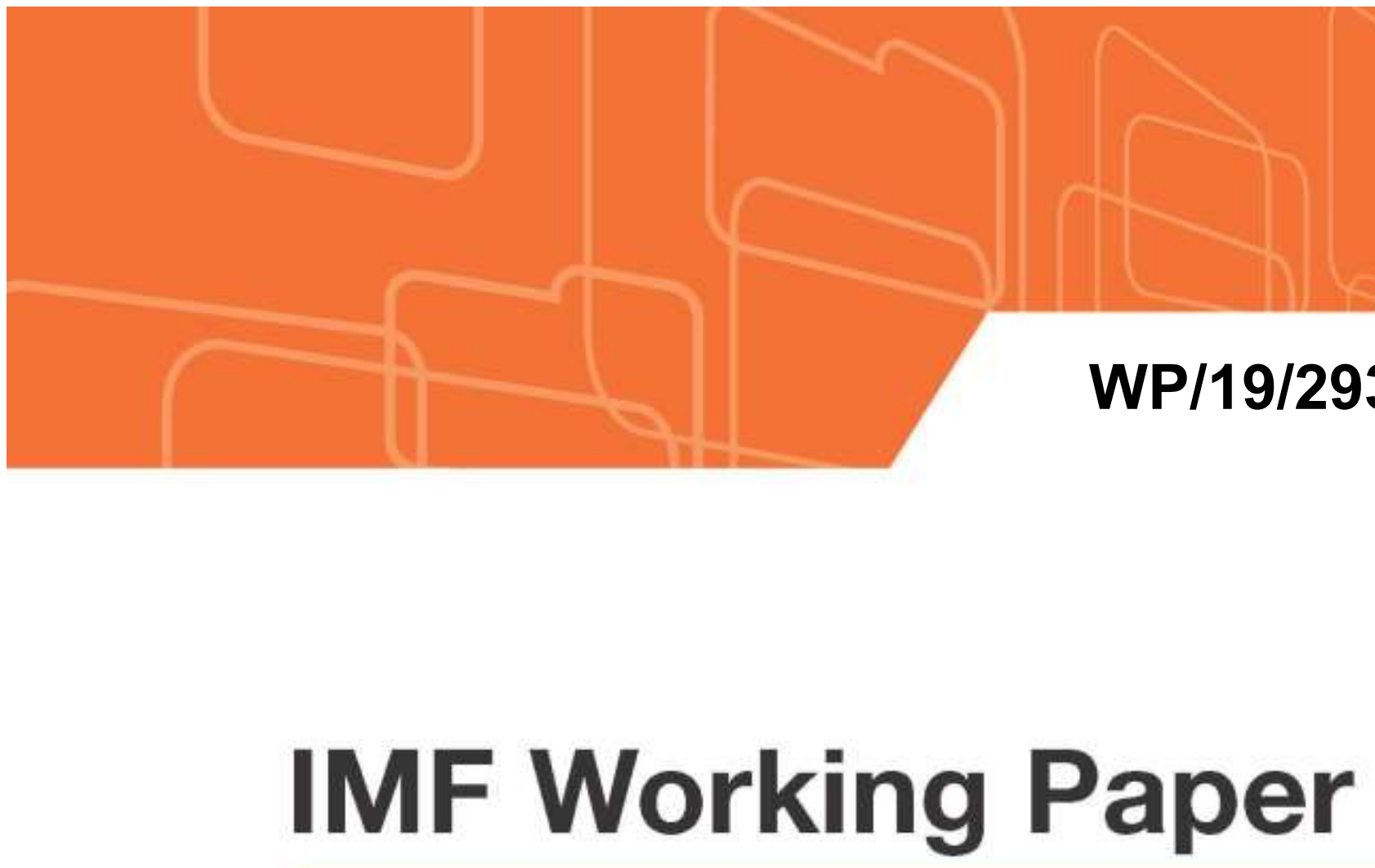

\title{
The Role of Board Oversight in Central Bank Governance: \\ Key Legal Design Issues
}

by Wouter Bossu and Arthur Rossi

IMF Working Papers describe research in progress by the author(s) and are published to elicit comments and to encourage debate. The views expressed in IMF Working Papers are those of the author(s) and do not necessarily represent the views of the IMF, its Executive Board, or IMF management. 


\title{
IMF Working Paper
}

\author{
Legal Department \\ The Role of Board Oversight in Central Bank Governance: \\ Key Legal Design Issues \\ Prepared by Wouter Bossu and Arthur Rossi \\ Authorized for distribution by Yan Liu
}

December 2019

IMF Working Papers describe research in progress by the author(s) and are published to elicit comments and to encourage debate. The views expressed in IMF Working Papers are those of the author(s) and do not necessarily represent the views of the IMF, its Executive Board, or IMF management.

\begin{abstract}
This paper discusses key legal issues in the design of Board Oversight in central banks. Central banks are complex and sophisticated organizations that are challenging to manage. While most economic literature focuses on decision-making in the context of monetary policy formulation, this paper focuses on the Board oversight of central banks-a central feature of sound governance. This form of oversight is the decision-making responsibility through which an internal body of the central bank - the Oversight Board-ensures that the central bank is well-managed. First, the paper will contextualize the role of Board oversight into the broader legal structure for central bank governance by considering this form of oversight as one of the core decision-making responsibilities of central banks. Secondly, the paper will focus on a number of important legal design issues for Board Oversight, by contrasting the current practices of the IMF membership's 174 central banks with staff's advisory practice developed over the past 50 years.
\end{abstract}

Author's E-Mail Address: WBossu@imf.org; ARossi@imf.org 
TABLE OF CONTENTS

PAGE

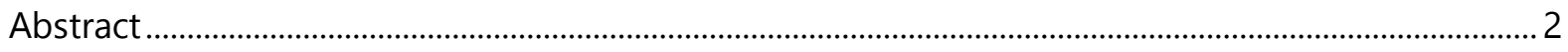

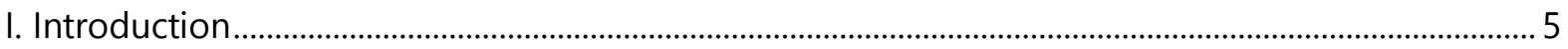

II. Governance, Decision-Making Structures and Oversight: a Conceptual Framework...................... 8

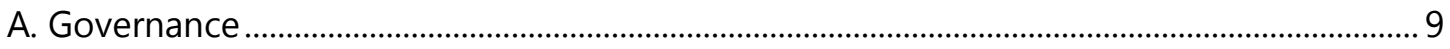

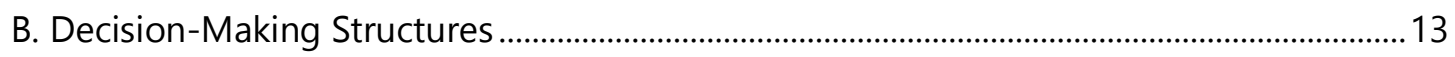

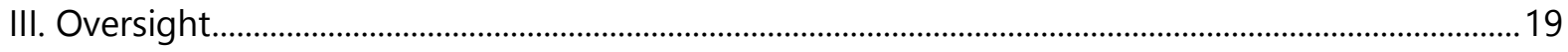

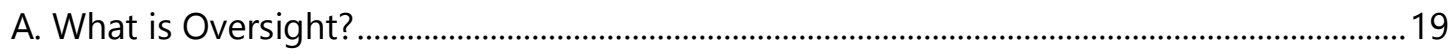

B. To whom the Oversight responsibility is entrusted: the Oversight Board ...........................25

C. How Board Oversight is conducted: Oversight Procedures..................................................33

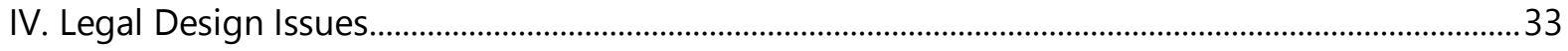

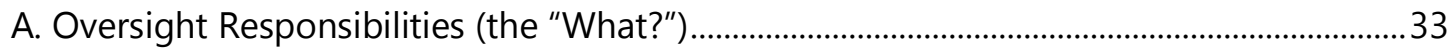

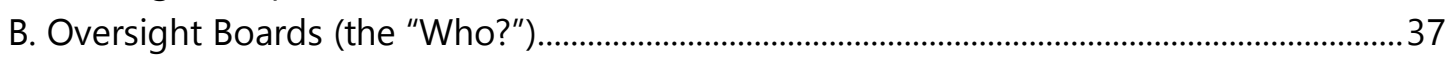

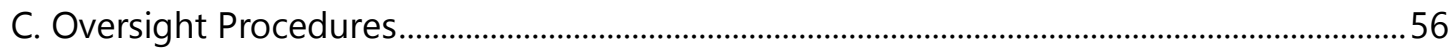

D. Oversight in Federal Central Banking Systems and Monetary Unions................................60

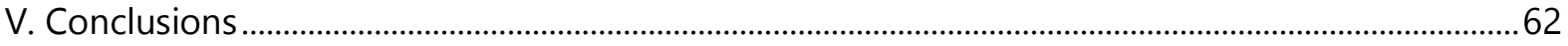

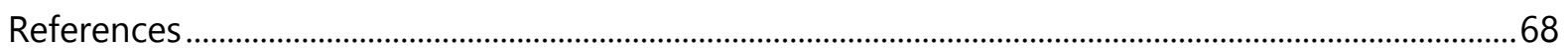

Boxes

1. Examples of Well-Drafted Oversight Responsibilities.......................................................................36

2. What is, and should be, the size of the Oversight Board? ..............................................................42

3. Quorum and Size of Non-Executive Majority on Boards of Directors..........................................57

4. Example of Well-Drafted Legal Provisions for Oversight Procedures................................... 59-61

Figures

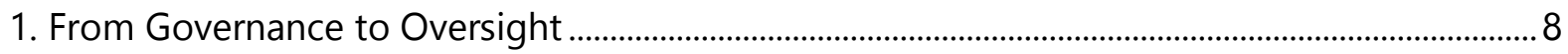

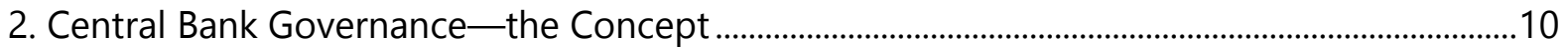

3. Decision-Making Structures of Central Banks.............................................................................14

4. Central Bank Decision-Making Responsibilities ...............................................................................15

5. Legal Framework for Central Bank Decision-Making Procedures ..................................................17

6. Oversight and Central Banks: A Multi-Faceted Concept....................................................................20

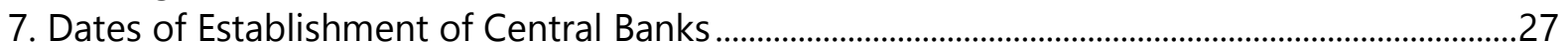

8. Oversight Boards and Executive Management in Central Banks.................................................31

9. Types of Oversight Boards and Monetary Policy Responsibilities ...............................................32

10. Executive/Non-executive Membership of Central Bank Boards of Directors ..........................39

11. Interaction between Size of Board, Quorum and Non-Executive Majority ..............................41

12. Requirement for Separation of Chair and Executive in Commercial Banks'............................46

13. Executive v. Non-Executive Chairs in Boards of Directors ...........................................................46

14. Percentage of Public Sector Oversight Board Members ..............................................................50

15.: Eligibility Criteria for Non-Executive Oversight Board Members in Central ...........................54 
Tables

1. Decision-Making Powers of Oversight Boards.

2. From Corporate Law Central Banks to Public Law Central Banks..................................................28

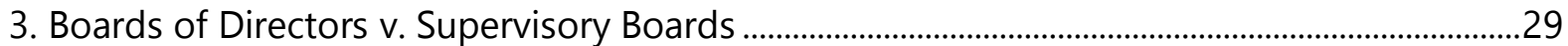

\section{Annexes}

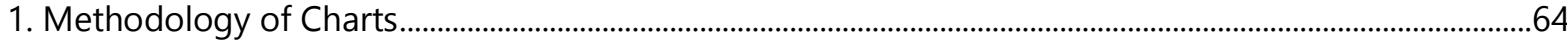

2. Presidential vs Collegial Model of Executive Management in Central Banks................................................67 
Quis custodiet ipsos custodes? Who guards the guardians?

Juvenal, Satire VI, lines 347-348

\section{INTRODUCTION ${ }^{1}$}

1. Central banks are uniquely complex institutions. Their modern appellation, ${ }^{2}$ which combines the adjective central and the substantive bank, is in fact a testimony to the difference between central banks and other public and private institutions. Central banks have, at the same time, a sovereign, complex public policy making mandate (the central) and an equally complex balance sheet (the bank). In that regard, central banks are different from (a) other governmental agencies, which often have public policy making mandates but typically do not have complex balance sheets, and (b) commercial banks, which have complex balance sheets but do not have to deploy these to pursue public policy objectives.

2. This makes central banks challenging organizations to manage. The complexity of managing central banks has recently increased due to the expansion of many of their balance sheets in response to the Global Financial Crisis and its aftermaths, and the eventual need for some degree of unwinding.

3. To ensure sound and effective decision-making, central banks need to have robust governance arrangements. The importance of effective governance arrangements for central banks has been explicitly recognized under two policies established by the IMF's Executive Board. The first such policy pertains to Safeguards Assessments, ${ }^{3}$ which, especially since the 2010 review,

\footnotetext{
${ }^{1}$ The authors are grateful to IMF staff who provided internal review comments as well as to David Archer, Elsie Addo Awadzi, Carine Chartouni, Blanaid Clarke, Peter Conti-Brown, Cristiano Cozer, Jean Pierre Deguee, Pasquale Di Benedetta, Natia Gvazava, Masaru Itatani, Barend Jansen, Rosa M. Lastra, Urs Lendermann, Fabian von Lindeiner, Tonny Lybek, Catalina Margulis, Manuel Monteagudo, Mohammed Nyaoga, Pierre Siklos, Mario Tamez, Hans Weenink and Paul Yuen for providing insightful comments on this paper. Obviously, any errors or omissions are the authors' alone. We are also indebted to ECB visiting counsel Panagiotis Papapaschalis who contributed to Annex 2. Finally, many thanks to the colleagues who have designed figures 2 and 3, Mmes. Li and Tuladhar for their research and Ms. Amon for formatting the paper.

${ }^{2}$ Central banks have existed for more than a century before being called as such: see Ugolini, S., The Evolution of Central Banking: Theory and History, Palgrave Studies in Economic History, p. 9. The term stems from the Bank of England, which had a special charter that gave the Bank a monopoly as a Joint Stock bank: only the Bank of England had the ability to issue shares to outside shareholders, as opposed to other banks which were much smaller partnerships. Because of its dominant size, the Bank of England required all other banks to centralize part of their gold deposits at the Bank of England allowing for a relatively stable banking system overtime, hence the name: central bank. See e.g. Bagehot, W., Lombard Street: A Description of the Money Market, Chapter 3; Galbraith, J.K., Money: Whence it Came, Where it Went, Chapter 4 "The Bank."

${ }^{3}$ In 2002, the IMF's Executive Board adopted a Policy requiring "safeguards assessments" of central banks of borrowing member countries. During the 2010 review of that policy, the Executive Board endorsed an update to the framework through a sharper focus on governance and risk management within the ELRIC framework:

(i) External audit mechanisms; (ii) the Legal structure and independence; (iii) the financial Reporting framework; (iv) the Internal audit mechanism; and (v) the internal Controls system used in conducting safeguards assessments. This focus was renewed during the 2015 Policy Review.
} 
has stressed the importance of central bank governance. The second policy is the one on governance and corruption, approved by the Executive Board in $2018 .{ }^{4}$

4. For central banks, the cost of governance failures is high. In addition to causing reputational damage, such failures can have a severe financial impact by giving rise to losses which could amount to percentage points of GDP. This in turn could lead to excessive external oversight (which may deteriorate into inappropriate interference) by the political bodies of the State, with ensuing reduced autonomy, a constrained mandate, and ultimately policy ineffectiveness. In other words, sound governance of central banks has a direct macro-economic relevance.

5. Effective Board oversight plays a critical role in ensuring central banks' sound governance. We define Board oversight as the decision-making responsibility through which an internal body of the central bank-the Oversight Board-ensures that the central bank is wellmanaged. As the highest decision-making bodies of central banks, Oversight Boards are the "last line of defense" in the broader internal governance structure of the central bank. Robust Board oversight is critical to (i) holding the central bank's internal decision-making accountable and (ii) ensuring that overall management is appropriate, compliant with legal requirements, and financially and operationally sound.

6. Board oversight in central banks and its legal design features have not been the center of attention of policy makers and academic research alike. International standards, and in particular the IMF's Code of Good Practices on Transparency in Monetary and Financial Policies (1999)_ currently under review-refer only indirectly to the role of Board oversight. ${ }^{5}$ In a way, this is logical, given the double focus of the Code on transparency on the one hand (as opposed to substance), and monetary policy (as opposed to broader central bank governance) on the other hand. Similarly, most academic research focuses on monetary policy decision-making within central banks, given the direct macro-economic impact of this issue. Some publications have sought to cover certain aspects of Board oversight, but from an economic perspective and still predominantly gravitating around the monetary policy formulation task of central banks. ${ }^{6}$

\footnotetext{
${ }^{4}$ See the Framework for Enhanced Engagement on Governance, adopted in 2018: one of the seven State functions assessed under this policy is Central Bank Governance and Operations. The Board Paper notes that "while Central Banks are often viewed as one of the most effective institutions within a country, there have, however, been cases where central banks have exhibited severe governance weaknesses." (p. 20)

${ }^{5}$ Section 1.1.7. of the Code states that "the procedure for appointment, terms of office, and any general criteria for the dismissal of (...) members of the governing body of the central bank should be specified in legislation." In case the Oversight Board would be entrusted with monetary policy formulation, Section 2.2 becomes relevant in that it requires that "information on the composition, structure and functions of that body should be publicly disclosed. Finally, Section 4.2 .2 requires that "internal governance procedures necessary to ensure the integrity of operations, including internal audit arrangements, should be publicly disclosed."

${ }^{6}$ In particular, see Lybek, T., and Morris, J., Central Bank Governance: A Survey of Boards and Management, IMF, WP/04/226; Berger, H., Lybek, T., and Nitsch, V., Central Bank Boards Around the World: Why Does Membership
} 
7. This paper aims to address this hiatus by discussing how Board oversight in central banks can best be legally designed. The paper will first (sections II and III) contextualize the role of Board oversight into the broader legal structure for governance and decision-making by considering this form of oversight as one of the core decision-making responsibilities of central banks. The second part of the paper (section IV) will focus on important legal design variables that provide a robust legal foundation for effective Board oversight. For a major subset of those variables (those dealing with the composition of Oversight Boards), the paper will summarize both the IMF's membership's current practices and the Fund staff's advisory practices:

- $\quad$ Current practices: The paper will give an overview of current practices among the entire IMF membership. This overview is based upon a rigorous legal analysis of all relevant central bank laws and other relevant legal instruments (e.g. constitution, by-laws) against the legal categories defined in the first part of the paper. For instance, data will be provided on the split between executive and non-executive members of Oversight Boards and the strength of the eligibility criteria of non-executive Board members. Annex 1 describes in detail the process and the methodology used to classify central banks' practices, including the design of the underlying database.

- $\quad$ Staff's advisory practices: Advice by Fund staff on central bank legal frameworks is provided mainly in the contexts of Fund-supported adjustment programs and technical assistance. The paper summarizes the long-standing advisory practices of the Fund's Legal Department, which implement key general legal principles into practical, countryspecific applications. In the absence of a formal substantive international standard on central bank governance, a set of comprehensive advisory practices honed over decades lay the foundation for staff's advice to Fund members. ${ }^{7}$

8. Specifically, the paper will seek to answer 3 central legal design questions:

- How are the activities comprising Board oversight defined in central bank laws?

- What legal forms do Oversight Boards take?

- $\quad$ How is Board oversight legally exercised?

9. Whilst answering those questions, it is important to acknowledge that sound legal frameworks are necessary, but not sufficient, to ensure sound governance. Ultimately,

Size Differ?, IMF, WP/06/281; Tuladhar, A., Governance structures and Decision-Making Roles in Inflation Targeting Central Banks, IMF, WP/05/183; BIS, Issues in the Governance of Central Banks, Report from the Central Bank Governance Group, 2009; and de Abreu Faria, F., and Ermes Streit, R., Governance in central banks: a comparative study of the governance practices used by the central banks of Brazil, Canada and England, Revista de Administracao Publica, 50 (5) (2016), p. 765-793.

${ }^{7}$ IMF staff has been advising on the design of central bank laws since the 1960s when, in the context of several Stand-By Arrangements (e.g., Somalia, Guatemala), IMF staff drafted and commented upon new central bank laws. Fund staff's views were early on codified: see in particular by former IMF counsel Aufricht, $\mathrm{H}_{\text {., Comparative }}$ Survey of Central Bank Law, 1965, in which the author compares the legislation of twenty-one countries chosen from the sterling area, Latin-America, and several European countries. 
governance is the sum of rules and people. And people operate in a broad contextual framework (also labelled "culture") where quality of institutions, rule of law, and broad respect for the autonomy of institutions constitute critical pre-conditions for sound governance: not even the best written piece of legislation can overcome weaknesses in these factors. This being said, while "human factors will always remain important to outcomes, (...) human behavior is subject to influence by structural and procedural aspects of the environment, ${ }^{8}$ and these are encapsulated in legal frameworks.

10. This paper will not deal with some other legal design variables that are also critically important for effective Board oversight, such as the personal autonomy of members of Oversight Boards (apart from the eligibility and incompatibility criteria) and the critical role that Audit and other specialized sub-committees of Oversight Boards can play to buttress the overall effectiveness of oversight. We believe both issues merit a separate paper. ${ }^{9}$

\section{Governance, Decision-Making Structures AND OVersight: A CONCEPTUAl FramewORK}

11. To properly understand the role of Oversight Boards in the broader governance arrangements of central banks, it is necessary to briefly consider the following two concepts. First, decision-making structures, which are often equated with governance, are a core, but certainly not the only, component of the governance of central banks, and indeed of any other public institution. Second, the decision-making structures of central banks have various conceptual components and it is necessary to analyze the concept of oversight through that lens. The sequencing of this discussion is summarized by the following figure.

\section{Figure 1. From Governance to Oversight}

\section{Governance}

Governance

Source: IMF staff.

\section{Decision-Making}

Structures

\section{Oversight}

\footnotetext{
${ }^{8}$ BIS, o.c., p. 77.

${ }^{9}$ On Audit Committees, see Sullivan, K, Camilleri, M., and Lybek, T., Audit Committees in Central Banks, IMF, WP/07/73, and Chamoun, E., and van Greuning, R., Effectiveness of Internal Audit and Oversight at Central Banks: Safeguards Findings, Trends and Observations, IMF, WP/18/125. A working paper on the legal parameters of personal autonomy is under preparation.
} 


\title{
A. Governance
}

12. Governance can be defined as the ensemble of structures and arrangements by means of which an organization makes decisions, in the pursuit of its mandate. Good governance balances effectiveness-when required, can decisions be taken adequately, effectively, and within the appropriate timeframe? — with soundness-are decisions appropriate, legally well-founded, and in line with the objectives of the institution? How this balance is struck may change depending on circumstances.

13. From a formal perspective, the governance of central banks is always established in, or pursuant to, the "central bank law." Because they are essentially creations of the State, central banks are established by a law, or a law authorizes their establishment through another legal instrument (e.g., through a corporate law procedure). This legislation, called "central bank law," operates as the "organic law" of the central bank and accordingly establishes the basic governance framework at the institution. ${ }^{10}$ Beyond primary law, related secondary legal instruments (e.g. by-laws, internal regulations, codes of conduct) often provide for the more detailed aspects of the decision-making processes (i.e. the procedures, as will be discussed below), which, from a practical perspective, are very important.

14. From a substantive perspective, "central bank governance" is a multi-faceted concept composed of four constitutive and interrelated components: the central bank's

\author{
i. Mandate; \\ ii. Autonomy; \\ iii. Transparency and Accountability; and \\ iv. Decision-Making Structures. ${ }^{11}$
}

\footnotetext{
${ }^{10}$ Increasingly, features of central bank governance can also be found in international treaties - that is for members of regional monetary unions-and in constitutions. For central banks of regional monetary unions, the relevant treaty will typically include a fairly comprehensive governance framework for the central bank-even if that framework is formally established as an annex of protocol to the main text of the treaty. In contrast, constitutions will typically only include a few provisions on the central bank, focusing on the establishment of the central bank, its legal status within the State apparatus, its objectives and sometimes its autonomy.

${ }^{11}$ This is a somewhat broader concept than the one used in other definitions of corporate governance. For instance, the Basel Committee on Banking Supervision (BCBS) defines corporate governance for banks as "a set of relationships between a company's management, its board, its shareholders and other stakeholders which provides the structure through which the objectives of the company are set, and the means of attaining those objectives and monitoring performance. It helps define the way authority and responsibility are allocated and how corporate decisions are made." BCBS, Guidelines-Corporate Governance Principles for Banks, 2015.
} 
We will briefly explain these concepts, which can visually be represented as follows:

\section{Figure 2. Central Bank Governance-the Concept}

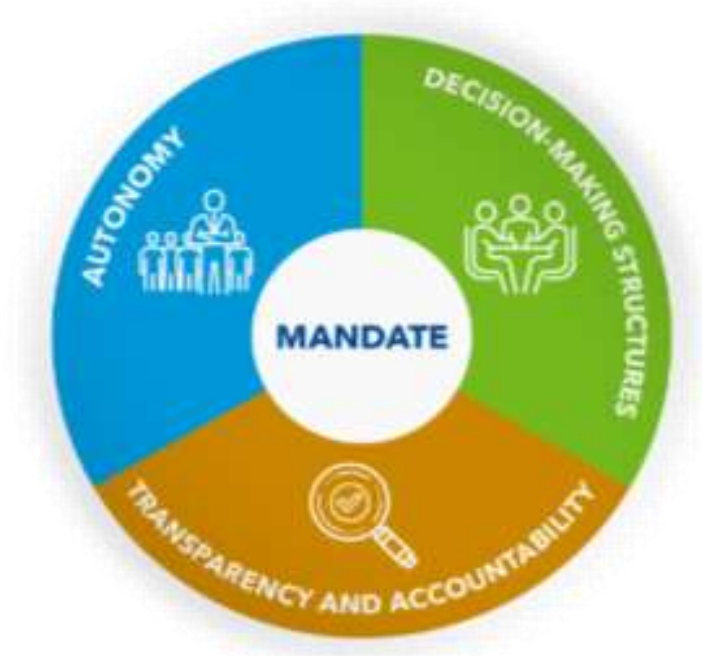

Source: IMF staff.

\section{Mandate}

"Within our mandate, the ECB is ready to do whatever it takes to preserve the euro. And believe me, it will be enough." (Mario Draghi, 2012)

15. The mandate is the core of a central bank's governance: it shapes the autonomy, transparency, accountability and decision-making structures of a central bank. The roots of the word mandate come from the Latin verb mandare, which means both to send and to instruct. It is indeed the State which has sent and instructed the central bank through its organic law: central banks are public law institutions and fulfill essentially sovereign functions delegated to them by the State. In line with general principles of administrative law (e.g., the attribution, conferral of powers or spécialité principles), central banks are only authorized to do what the law requires and allows them to do, explicitly or implicitly ("implied/incidental powers"). Moreover, some central bank laws explicitly prohibit certain operations. ${ }^{12}$ Hence, the sum of what is required,

\footnotetext{
${ }^{12}$ While the enabling provisions (i.e., what is required and allowed) of a central bank law are often drafted in rather general wording, the prohibitions are typically worded more specifically. As a result, they can offer a somewhat higher degree of legal certainty as to what a central bank cannot operate in.
} 
allowed and prohibited constitutes the central bank's mandate. Actions of a central bank beyond its mandate are vulnerable to political and legal challenges. ${ }^{13}$

16. A central bank's mandate can be divided into the following three related concepts:

- The objectives are the goals that the central bank should aim to accomplish (the "why"). Most central bank laws lay down a number of general objectives of the central bank, ${ }^{14}$ which typically include the pursuit of price stability, financial stability and support for the economic policies of the government. ${ }^{15}$

- The functions are the areas of activities that a central bank is mandated to undertake to achieve its objectives (the "what"). Central bank laws often establish a list of core functions, such as (i) the formulation and implementation of monetary policy, (ii) the implementation of exchange rate policy, (iii) the holding and management of a country's official foreign reserves, and (iv) the promotion of a well-functioning payment system.

- The powers are the specific legal tools at the disposal of a central bank to implement its functions (the "how"). ${ }^{16}$ These powers can be of a private law (e.g., the authorization to conclude a wide range of financial contracts) or a public law (e.g., the imposition of minimum reserve requirements upon banks) nature.

\section{Autonomy}

"Do you want us to lose our jobs?" (anonymous Federal Reserve Board member after WWII)17.

\footnotetext{
${ }^{13}$ These challenges can be brought on grounds of the ultra vires doctrine, détournement de pouvoir or similar legal concepts. The ECB's Outright Monetary Transactions' monetary policy program was legally challenged on grounds that (i) it was not monetary policy and (ii) that the program violates the Treaty on the Functioning of the European Union on the monetary financing prohibition to member states. The European Court of Justice confirmed the legality of the Outright Monetary Transactions Program. See case C-62/14, 16 June 2015.

${ }^{14}$ Some central banks have not only general objectives, but also objectives assigned to specific functions. For instance, the Bank of England has a specific objective for its monetary policy function, and the European System of Central Banks has a specific objective ("smooth operation") for its payment system function.

${ }^{15}$ The objectives of a central bank should always be established taking into account the monetary arrangement of the country. The widespread reference to price stability should be seen in the context of the mainly floating exchange rates under "Bretton Woods 2." Before that, the "governing objective" of central banks was to maintain exchange rate stability under the "Bretton Woods 1" system and the pre-war Gold Standard. See Friedman's chapter VIII Should there be an independent Monetary Authority, p.230 in Yeager's In Search of a Monetary Constitution, 1962. "Their main objective was to maintain convertibility of the currency into gold." See F. Capie, C. Goodhart and N. Schnadt, The development of central banking, 1994, p.15. For an overview of the mandate that eight major central banks had in 1961, see BIS, Eight European Central Banks, 1963.

${ }^{16}$ Central banks have also non-legal tools at their disposal, e.g. communication strategies (forward guidance).

${ }^{17}$ Shortly after World War II, the Federal Reserve's bond-support program was questioned, and Milton Friedman argued that it should be dropped. An unnamed member of the Reserve Board largely agreed with Friedman but asked "Do you want us to lose our jobs?" See Friedman's chapter VIII Should there be an independent Monetary Authority, p.235 in Yeager's In Search of a Monetary Constitution, 1962.
} 
17. To be effective, central banks must enjoy a high level of autonomy vis-à-vis both political institutions and private economic interests. ${ }^{18}$ The autonomy of central banks is commonly ${ }^{19}$ analyzed through the lens of four related but distinct sub-concepts: ${ }^{20}$

- institutional autonomy entails that the central bank, qua institution, should not be influenced by the State or private third parties in its decision-making in the context of the performance of its functions, e.g. through ministerial instructions;

- $\quad$ functional autonomy points to the capability of the central bank to implement its functions without direct governmental interference, e.g. by prior approval of central bank decisions;

- $\quad$ personal autonomy ensures that key decision makers of the central bank (Governor and members of Executive Boards, Monetary Policy Committees and Oversight Boards) are autonomous from political and private economic interests; and

- $\quad$ financial autonomy entails the capability of the central bank to pursue its mandate by way of the financial means required to do so. ${ }^{21}$

18. Illustrating the link between the mandate and autonomy, the level of autonomy of the central bank can differ depending on the various functions of a central bank. ${ }^{22}$ Consider the functions of monetary policy formulation, bank resolution, and fiscal agency of the State. Monetary policy formulation will require the highest level of autonomy. Bank resolution (if entrusted to the central bank) can take place at a lower level of autonomy in case the State provides financing to rescue a systemically important institution. Fiscal agency in turn implies by definition that the State as principal instructs the central bank as agent.

\footnotetext{
${ }^{18}$ For a general legal analysis of this topic, see Monteagudo, M., La independencia del Banco Central, BCRP; IEP, Universidad del Pacifico, 2010.

${ }^{19}$ This analytical framework was developed by the EU in the context of the preparation of the monetary union. The ECB currently utilizes this framework in its bi-yearly "convergence reports" and sporadically in its opinions.

${ }^{20}$ Another common analytical approach is to distinguish between goal, target and instrument autonomy: see Lybek, T., Central Bank Autonomy, Accountability, and Governance: Conceptual Framework We agree with the author that these different types of autonomy can have an impact on the mandate and decision-making structures of central banks.

${ }^{21}$ Central banks are indeed financial institutions with a balance sheet that comprises financial assets and liabilities. The idiosyncratic feature of central banks is that the objective of price stability is achieved mainly by expanding or shrinking their balance sheet in function of broader macro-financial conditions. To do so, central banks must control autonomously the size and composition of their balance sheet.

${ }^{22}$ See Bossu, W., Hagan, S., and Weenink, H., Safeguarding Central Bank Autonomy: the role of transparency and accountability, in "ECB Legal Conference 2017-Shaping a New Legal Order for Europe: a tale of crisis and opportunities," p. 36-37. See also, Lastra, R., International Financial and Monetary Law (2 ${ }^{\text {nd }}$. Ed.), p.67.
} 


\section{Accountability and Transparency}

"Sunlight is said to be the best of disinfectants." - Justice Louis Brandeis

19. Given that central banks exercise sovereign functions that are the final responsibility of the State, robust accountability and transparency mechanisms are a critical counterbalance for their high level of autonomy. These mechanisms must be shaped by the broader constitutional, political and societal parameters of the country. It is now common practice that central banks are required to be accountable for the execution of their mandate to both the State institutions (Executive, Legislative and Judiciary) and the public at large. ${ }^{23}$ For their accountability to work, central banks must be subject to robust transparency requirements to inform stakeholders about their policy formulating decisions and financial position. Moreover, highlighting another conceptual link reflected by Figure 1, robust Board oversight as discussed in this paper plays a critical role as enabler of high levels of transparency and strong accountability. ${ }^{24}$ This being said, the transparency imposed upon a central bank should be reasonable and not disproportionate, by potentially hindering the fulfillment the central bank's mandate. ${ }^{25}$

\section{Decision-Making Structures}

20. As any other legal entity, central banks act through decision-making structures. This concept is critical to understand the role and central design features of Oversight Boards and will be discussed in detail in the next sub-section.

\section{B. Decision-Making Structures}

21. The decision-making structures of central banks are composed of the following three sub-concepts:

- $\quad$ The exercise of decision-making responsibilities ("what" must be decided?)

- $\quad$ By decision-making bodies ("who" must decide?)

- $\quad$ Pursuant to decision-making procedures ("how" are decisions made?)

\footnotetext{
${ }^{23}$ For instance, Section 2B(c) of the Federal Reserve Act as amended through P.L. 115-174, enacted May 24, 2018 now reads "The Board shall place on its home Internet website, a link entitled "Audit", which shall link to a webpage that shall serve as a repository of information made available to the public for a reasonable period of time, not less than 6 months following the date of release of the relevant information (....."

${ }^{24}$ For instance, establishment by the Oversight Board of adequate financial reporting standards and a strong internal controls framework will contribute to enhancing respectively transparency and accountability.

${ }^{25}$ For instance, Freedom of Information legislation should not require a central bank to divulge information that puts at risk financial stability or the security of banknote distribution. See on this, Monteagudo, M. Central banks and ethics: the virtual paradox of transparency and confidentiality mandates, in Russo, C., Lastra, R., M. and Blair W., 2019, Research Handbook on Law and Ethics in Banking and Finance
} 
Figure 3. Decision-Making Structures of Central Banks

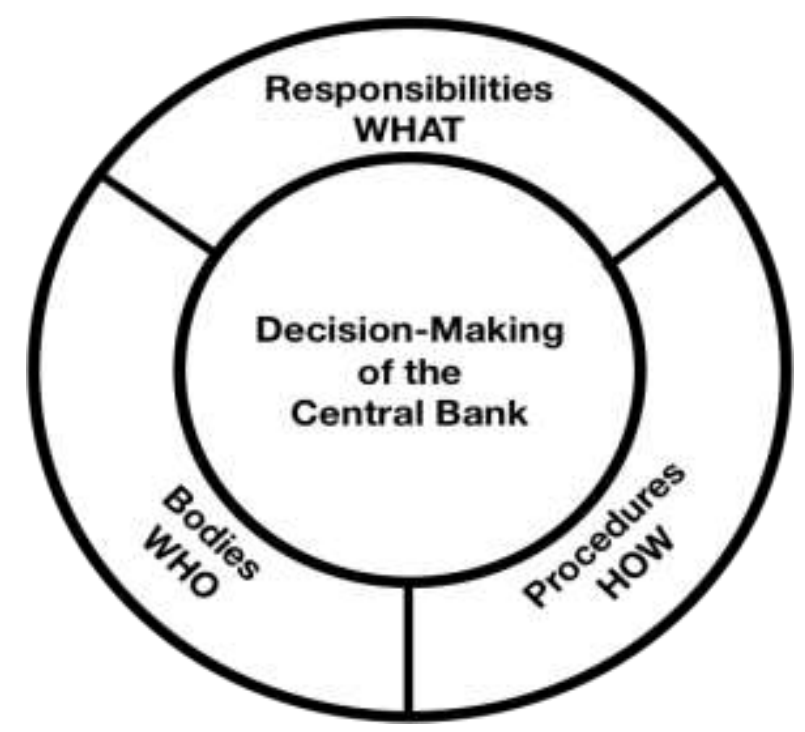

Source: IMF staff.

\section{Decision-Making Responsibilities}

22. Decision-making responsibilities are the categorization of the types of decisions that must be taken by an institution to execute its mandate. In light of the specific nature of central banks, central bank laws need to allocate four distinct decision-making responsibilities to one or more bodies of the central bank. ${ }^{26}$ Two of those are idiosyncratic to many public agencies: (i) public policy formulation and (ii) regulatory decision-making (the central). Two decisionmaking responsibilities are common to almost any organization of a certain size: (i) executive management and (ii) oversight (the bank).

- $\quad$ Public Policy Formulation: This "sovereign" decision-making responsibility concerns the formulation of the public policies which have been entrusted by the State to the central bank by means of the central bank law. In addition to monetary policy, these public policies typically pertain to exchange rates (within the exchange rate regime as formulated by government), financial stability, payment systems soundness, and the collection, production and distribution of statistical information.

- $\quad$ Regulatory Decision-Making: This second "sovereign" decision-making responsibility concerns the adoption of normative decisions vis-à-vis third parties. Many central banks are empowered to issue generally binding norms (often called "regulations," "rules" or

\footnotetext{
${ }^{26}$ In fact, some central bank laws allocate even other tasks to distinct bodies. A typical example is the "sanctioning committees" who are charged with imposing administrative sanctions on supervised entities.
} 
"directives") to implement monetary, exchange rate, statistical and supervisory policies. Moreover, central banks typically have the power to take individually binding decisions toward entities or persons that fall under their jurisdiction: e.g., the imposition of fines for breach of minimum reserve obligations.

- $\quad$ Executive Management: This decision-making responsibility entails the executive, or "day-to-day," management of a central bank. ${ }^{27}$ This responsibility includes the power to appoint, promote and dismiss staff, to implement monetary and other public policies entrusted to the central bank, to enter into financial and non-financial contracts, and to legally represent the central bank.

- $\quad$ Oversight: This decision-making responsibility is the subject matter of this paper and will be defined and discussed in more detail below (see section III).

Figure 4. Central Bank Decision-Making Responsibilities
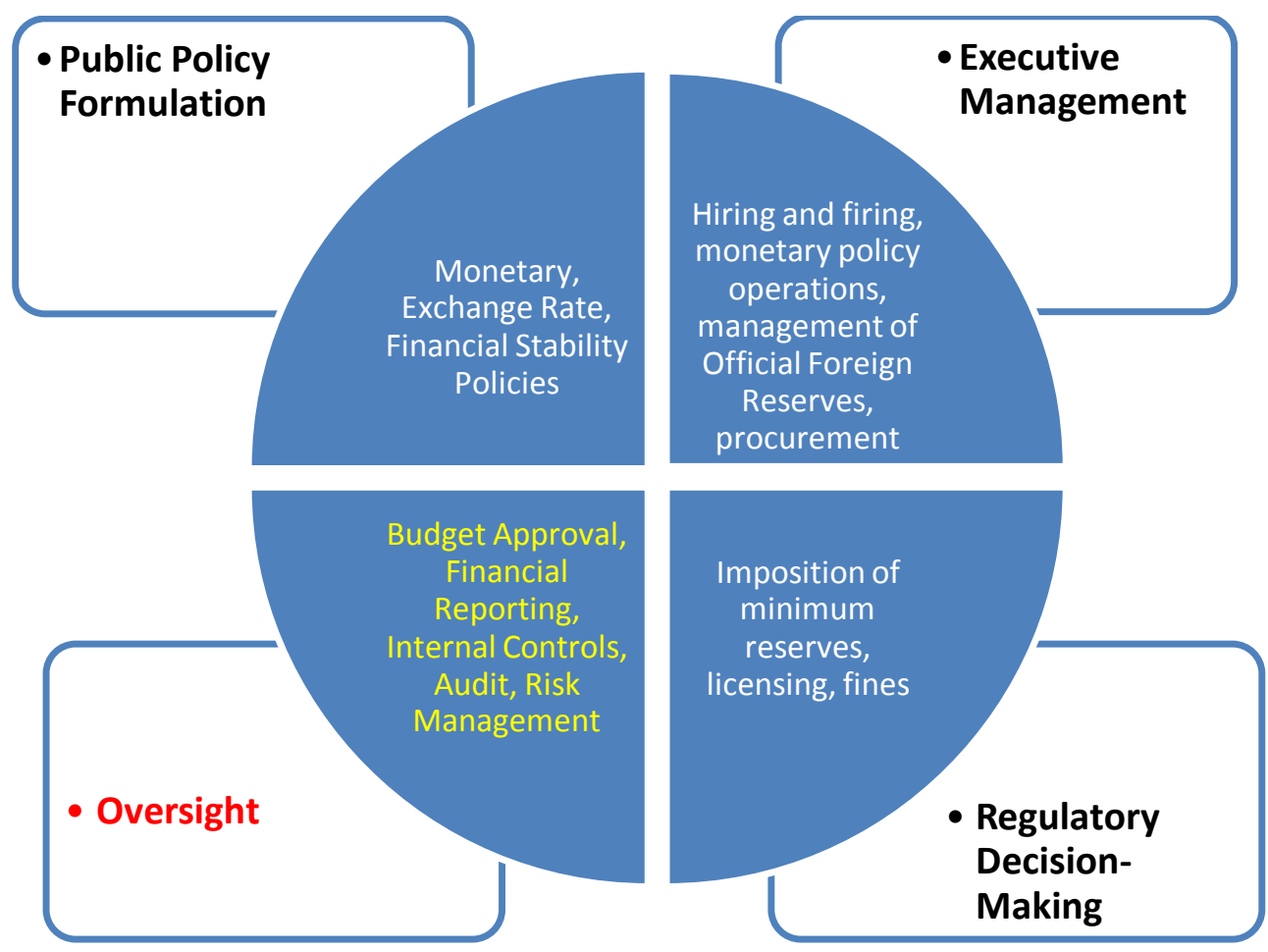

Source: IMF staff.

\section{Decision-Making Bodies}

\footnotetext{
${ }^{27}$ As a legal matter, the concept of "executive management" should be distinguished from the one of "administration." Several central bank laws entrust the administration of the central bank to the Board of Directors (while confirming the role of the Governor as chief executive officer). The legal concept of administration includes the formulation of the strategy of the central bank as well as an oversight role, as defined in para. 31.
} 
23. Central banks typically have two to three distinct decision-making bodies, to which one or more of the above-mentioned four decision-making responsibilities should be allocated. We will here briefly describe those bodies, and summarize how central bank laws allocate decisionmaking responsibilities to them:

- $\quad$ Governor or Executive Board-The executive management of the central bank is typically entrusted to either a single official (the Governor) - this is called a "presidential" model—or to an Executive Board-type of structure-this is called a "collegial" model (see Annex II). ${ }^{28}$ In a number of central banks, the executive management body is also charged with public policy formulation. In some central banks, this body is charged with general regulatory decision-making, and, in probably all central banks, with individual regulatory decision-making.

- Board of Directors or Supervisory Boards-As discussed in more detail in the next subsection, these Boards, which come atop the executive management body, are entrusted with the oversight responsibility. Boards of Directors are often also charged with public policy formulation and general regulatory decision-making responsibilities, and in some central banks, even with (major) individual regulatory decision-making responsibilities, e.g., to grant or withdraw a banking license. These Boards are the subject matter of this paper.

- $\quad$ Specialized Policy Formulating Committees-Some central bank laws allocate one or more public policy formulation responsibilities to a specialized committee. In most instances, this concerns monetary policy formulation (see also para. 58 and footnote 61), but in a few cases the formulation of other policies (micro-prudential supervision, payment system oversight, macro-prudential oversight) has also been allocated to a specialized committee. In rare cases, ${ }^{29}$ these committees are also charged with certain general regulatory decision-making responsibilities.

\section{Decision-Making Procedures}

24. The decision-making procedures lay down "how" decisions are taken within a central bank. In other words, these procedures determine the modalities pursuant to which the competent bodies are executing their decision-making responsibilities. Examples of such modalities are the frequency with which a decision-making body meets, the quorum required to have a valid decision, with which majority it decides, and what transparency is to be given to

\footnotetext{
${ }^{28}$ The Bank of England and Banque de France have presidential models, which have been replicated by their respective former colonies. The collegial model was traditionally found in countries of the Germanic legal tradition. Ukraine and the CEMAC (BEAC) are examples of countries that recently shifted toward some form of collegial model.

${ }^{29}$ For instance, in Israel, the Monetary Committee is empowered to issue directives regarding the holding of liquid assets by banks (Art. 15.4 and 38).
} 
decisions taken, e.g. publication of minutes. ${ }^{30}$ These modalities should not be underestimated, as they are a key variable capable of shaping the outcome of the decision-making: major procedural weaknesses can undermine the functioning of the decision-making body and even the effectiveness of the adopted decisions.

25. How are the procedural aspects of central bank decision-making legally established? In contrast to the decision-making responsibilities and bodies, the decision-making procedures are not necessarily established in the central bank law alone. Rather, those procedures are often established by way of a multi-layered legal framework in the form of a pyramidal system. In theory, the constitution could include procedural rules. The basic procedural rules are established in the central bank legislation (or a treaty for regional monetary unions). Under this, the By-Laws of the central bank establish the more detailed aspects of the decision-making procedures. ${ }^{31}$ Finally, at the lowest level, the internal organizational regulations and/or decisions of the decision-making bodies establish the more detailed rules regarding such decisions.

\section{Figure 5. Legal Framework for Central Bank Decision-Making Procedures}

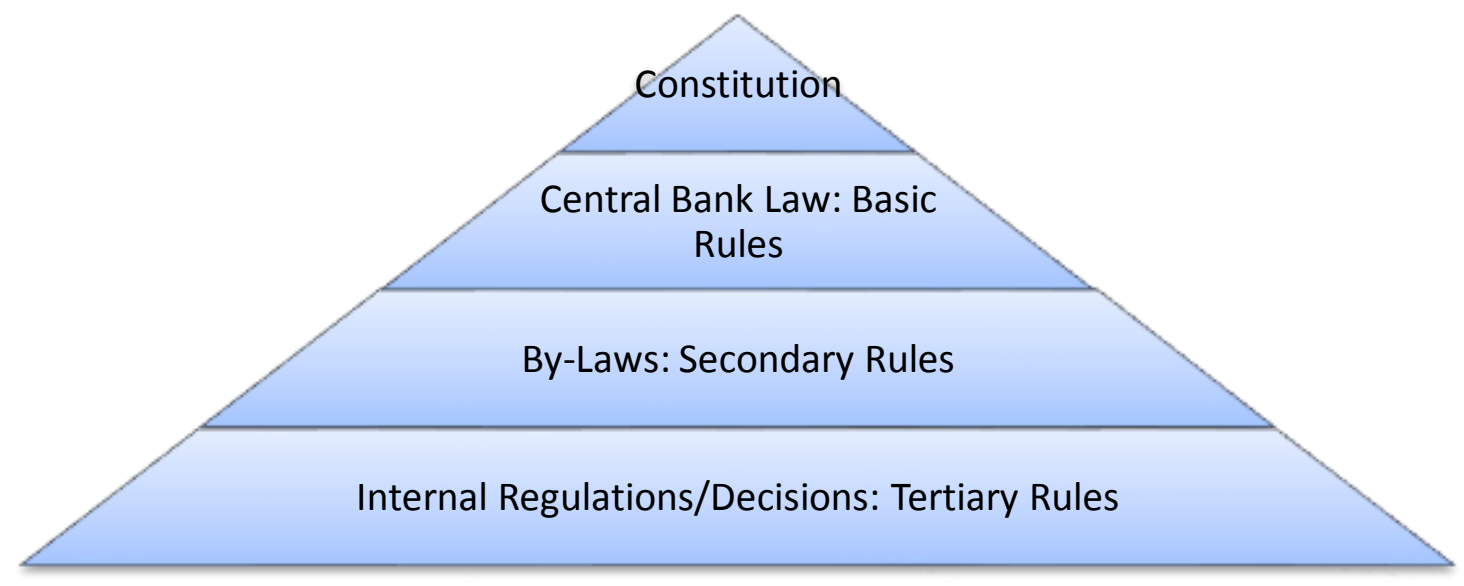

Source: IMF staff.

\footnotetext{
${ }^{30}$ Other procedural modalities could pertain to (i) the obligation to give reasons for a decision and (ii) the confidentiality regarding the discussion leading up to the decision.

31 By-Laws and internal regulations and/or decisions are easier to adopt than legislation, and hence more flexible to adjust to changing circumstances. At the same time, the political institutions have a stake in how the decisionmaking bodies of central banks reach their decisions. Therefore, it is common to see the procedural rules spread out over three/four levels of legal instruments. Interestingly, sometimes the approval procedure for the By-Laws involves some degree of political involvement, e.g. consent by the Minister of Finance. This is understandable, given the interest of the latter in sound central bank governance, and the fact that in many countries the Minister of Finance is politically responsible for the actions of the central bank.
} 


\section{General Legal Principles}

26. In allocating decision-making responsibilities to decision-making bodies, central bank laws should comply with the following three general legal principles.

27. "No Gaps, No Overlaps" To allow the institution to function effectively, a central bank law should allocate comprehensively and with precision all decision-making responsibilities to and between the central bank's decision-making bodies. ${ }^{32}$ Well drafted laws should avoid gaps and overlaps in this respect. For instance, the law should be clear as to which bodies are responsible for the formulation and implementation of monetary policy, respectively. While overlaps are avoided by clear drafting, gaps can be avoided by specific legal techniques, for instance, by allocating the so-called "residual powers" - the powers that are not explicitly allocated in the central bank law to any decision-making body-to one specific decision-making body of the central bank.

28. "Checks and Balances" At the same time, central bank laws need to provide for robust "checks and balances" with a view to avoid excessive concentration of power, which may hinder sound decision-making. While "presidential models" of executive management certainly have some advantages (e.g. swift and unified decision-making), experience has also shown that such a model can evolve into "imperial" management practices, especially where the powers of the Governor are insufficiently checked. This risk cannot be underestimated, as $83 \%$ of central banks of the Fund membership have an executive management structure that is highly concentrated in the person of the Governor (see Annex II).

29. Lack of sufficiently strong "checks and balances" can cause problematic policy making, corruption and other malpractices in the central bank. To avoid this, carefully designed central bank laws seek to establish "checks and balances" both within (e.g., by collegial executive management) and between (e.g., between the Oversight Body and executive management) the decision-making bodies. As will be discussed below, appropriate rules on composition (e.g., majority of non-executives in Oversight Body) and the chair can buttress the quality of those "checks and balances."

30. "Unicity" As a legal entity, the central bank should be one and indivisible. Care must be taken to avoid that the decision-making of the central bank does not become fractured, i.e. when decision-making bodies of the central bank take decisions that are not mutually coherent, or even contradictory. This could occur when aspects of a specific decision-making responsibility (e.g., executive management) are allocated to two not hierarchically related bodies.

\footnotetext{
${ }^{32}$ See, for State-owned enterprises, paragraph 4 of the G20/OECD Principles of Corporate Governance, 2015.
} 


\section{OVERSIGHT}

31. In this section, we will (1) define and contextualize the concept of oversight as a decisionmaking responsibility ("what?"), (2) discuss which decision-making body needs to be entrusted with this responsibility ("who?") and (3) briefly stress the importance of the procedural aspect of the exercise of this responsibility ("how?").

\section{A. What is Oversight?}

\section{Definition}

32. We define "oversight" for the purpose of this paper as the decision-making responsibility through which an organization and its stakeholders ascertain and ensure that the organization is well managed. It is all but impossible to generally define what "well managed" exactly means. This being said, the focus of oversight is on ensuring that an organization operates within its legal boundaries, is financially and operationally sound, utilizes its financial resources effectively and efficiently, and is transparent and accountable to its stakeholders.

33. This paper focuses on a key aspect of the oversight within the central bank, and more specifically on how this responsibility can best be legally designed, allocated to, and exercised by an internal decision-making body—the "Oversight Board"—of the central bank. Hence the notion that this "Board oversight" is part of the broader internal oversight of the central bank (see para. 39). While allocated to an internal body, this form of oversight over the central bank is exercised on behalf of the State and ultimately also on behalf of society.

\section{The Broader Context}

34. Contrasting the paper's concept of Board oversight with the broader oversight over, and accountability by, central banks helps to understand what makes this form of central bank oversight so special. The complex relationship between the various aspects of oversight and accountability is illustrated by Figure 6 . The paper deals with the relationship reflected by the yellow arrow. 
Figure 6. Oversight and Central Banks: A Multi-Faceted Concept

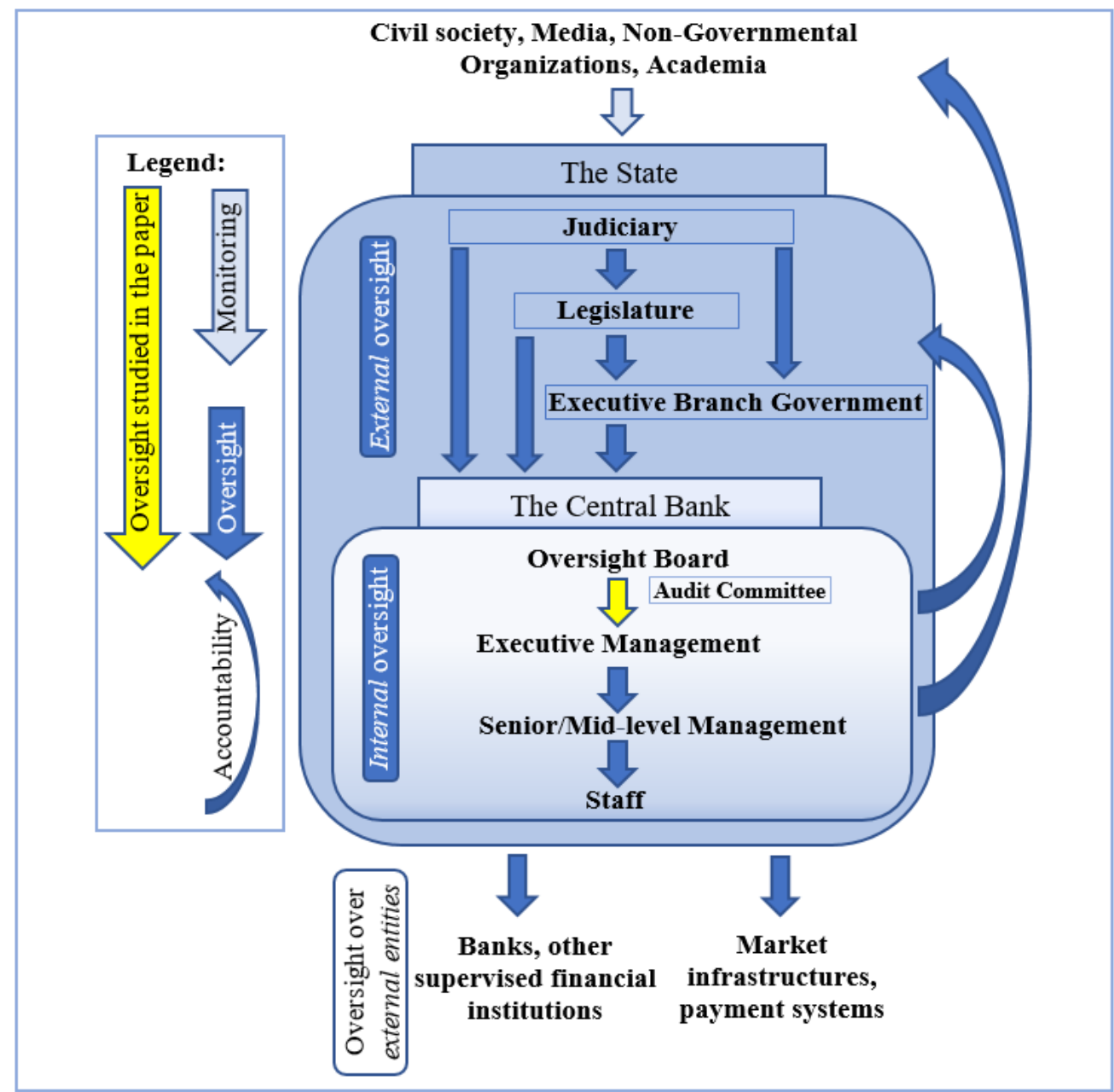

Source: IMF staff.

\section{External Oversight}

35. Board oversight - with its internal component-must first be distinguished from external oversight over the central bank by the State institutions.

- $\quad$ On the one hand, as principal of the sovereign State-functions delegated to the central bank and owner of the central bank's capital, the State and its institutions have a fundamental right to exercise external oversight over the central bank, which must be accountable to the State, as a counterpart for its autonomy. This external oversight can be exercised by the Executive, Legislature and Judiciary, assisted in some cases by an external council, government commissioners, or Supreme Audit Bodies. ${ }^{33}$ The scope of

\footnotetext{
${ }^{33}$ In contrast, the independent external auditors of central banks assist mainly the internal Oversight Body, although they also contribute to external oversight, in the sense that they certify also to the benefit of the external bodies that the financial statements of the central bank offer a fair and true view of the central bank's financial position.
} 
this external oversight can be wide, ranging from the appropriateness of the public policy formulation to the legality of the central bank's actions. ${ }^{34}$

- $\quad$ On the other hand, external oversight should be limited, for the following three reasons. First, the external oversight framework should take into account that a major component of the oversight responsibility has been entrusted to an internal body of the central bank. Secondly, given the specific nature of central banks, external oversight must be balanced with autonomy. If the Executive, Legislature and Judiciary were capable to substitute their judgment to that of the central bank, the public policy formulation and regulatory decision-making functions would almost inevitably suffer from State influence. Thirdly, the State institutions will often lack the expertise and access to confidential information to justify too broad oversight powers.

36. External oversight can certainly entail the taking of decisions. For instance, there are central bank laws that require the Minister of Finance to approve some important aspects of the governance of central banks, such as the By-Laws, the appointment of external auditors, and the constitution of special reserves. When appropriately designed, there is nothing inherently wrong with such an approach.

37. However, the decision-making aspect of external oversight by State institutions is often limited, including through specific legislative provisions. In particular, it is common that State institutions can assess and judge, but not substitute their decisions to, those of the central bank. For instance, the Executive and Legislature can assess and question the central bank on monetary policy formulation, but in most countries, they cannot take (or modify) monetary policy decisions instead of the central bank, nor instruct the central bank to take a monetary policy decision in any direction. In a similar vein, the Judiciary can typically review the legality of certain types of central bank decisions, but in many countries, legislation will limit the scope of that review. ${ }^{35}$

\section{Monitoring}

38. The paper's concept of oversight must also be distinguished from monitoring by civil society, to whom the central bank can be accountable. This monitoring consists of the ability, by law or not, to verify that a central bank exercises its decision-making powers appropriately, but without the attribution of any decision-making powers to enable such monitoring. This distinguishes monitoring from (external and internal) oversight.

\footnotetext{
${ }^{34}$ The legality of a central bank's action could thus fall under both internal and external oversight, for instance in case of behavior sanctioned by penal law. In some cases, the law provides an explicit mechanism for connecting internal and external oversight. For instance, when the Oversight Body detects criminal behavior, it might be under a duty to report this behavior to the public prosecutor's office.

${ }^{35}$ E.g., by a higher liability threshold or by limiting the powers of the Courts to pecuniary damages, thus prohibiting that Courts reinstate bank licenses previously withdrawn by the central bank or nullify bank resolution decisions of banks that have been completely liquidated.
} 


\section{Internal Oversight}

39. Thirdly, this paper will focus on the core aspect of oversight, namely on the role that Oversight Boards play in overseeing the top management of central banks. This Board oversight is of course part of a broader concept of internal oversight, which as a function runs through the entire organization of the central bank, and includes also oversight by Executive Management over staff, including through senior and mid-level managers.

\section{Financial Sector Oversight}

40. Fourth, Board oversight in central banks must be distinguished from central bank oversight over financial structures operating outside the central bank (e.g., financial institutions or payment systems), which is a different concept and is more akin to the supervisory functions of the central bank, albeit with a focus on operational instead of on prudential risks.

\section{Board Oversight as a Decision-Making Responsibility}

41. The Board oversight contemplated by this paper is inherently a decision-making activity. Oversight certainly is a broad concept. For instance, oversight entails the right of the Oversight Board to broadly discuss the activities of the organization and its other decision-making bodies. However, without decision-making powers, Board oversight would amount to mere monitoring (see Figure 6 above).

42. Specifically, the oversight responsibility entails the power to adopt certain key (i) general and (ii) specific decisions of an institutional nature:

- $\quad$ General decisions-The Oversight Board should have the legal power to adopt the internal organizational policies and regulations of the organization.

- $\quad$ Specific decisions-The Oversight Board will operationalize those internal policies by the adoption of specific oversight decisions. In some countries, this includes more operational decisions that go beyond "day-to-day" management, such as the opening/closing of branches or the acquisition of premises.

Table 1 provides an overview of the general and specific decision-making powers that typically accrue to Oversight Boards. 
Table 1. Decision-Making Powers of Oversight Boards

\begin{tabular}{|c|c|}
\hline General: Internal Organizational Policies & Specific: Oversight Decisions \\
\hline \multicolumn{2}{|l|}{ Internal Controls Framework } \\
\hline Budget Execution Framework & Approval of Annual Budget ${ }^{36}$ \\
\hline Basic Organizational Principles & Approval of Organizational Structure \\
\hline Financial Reporting Framework & Approval of Annual Financial Statements \\
\hline Audit Framework & $\begin{array}{l}\text { Appointment of External Auditor(s) } \\
\text { Appointment of Chief Internal Auditor }\end{array}$ \\
\hline \multicolumn{2}{|l|}{ Risk Management Framework } \\
\hline \multicolumn{2}{|l|}{$\begin{array}{l}\text { Official Foreign Reserves Management } \\
\text { Framework }\end{array}$} \\
\hline Human Resources Framework & $\begin{array}{l}\text { Appointment of senior executives } \\
\text { (sometimes) }\end{array}$ \\
\hline Procurement Framework & $\begin{array}{l}\text { Approval of Major Agreements and } \\
\text { Contracts, incl. purchases of premises } \\
\text { (sometimes) }\end{array}$ \\
\hline \multicolumn{2}{|l|}{ IT Security Framework } \\
\hline Code of Conduct, Code of Ethics & \\
\hline Compliance Framework & \\
\hline
\end{tabular}

Source: IMF staff.

\section{Interaction between Board Oversight and the Other Decision-Making Responsibilities}

43. Effective Board oversight is crucial to the sound governance of central banks: it will lessen the probability that the institution operates outside its mandate, thus avoiding political criticism, costly litigation and reputational harm to the central bank. Moreover, a highly qualified Oversight Board also can play an advisory role towards other decision-making bodies, which will enhance the quality of their decisions. ${ }^{37}$

\footnotetext{
${ }^{36}$ There are central banks whose organic law establishes that the annual budget and annual financial statements are approved by the executive management body, but that process is overseen by the Oversight Board.

${ }^{37}$ For a detailed discussion of the dual role that Boards have as an advisor as well as a monitor of management, see Adams, R., and Ferreira, D., A Theory of Friendly Boards, Stockholm School of Economics, 2005.
} 
44. At the same time, Board oversight must also be circumscribed, lest it overlap with, or unduly constrain, one or more of the three other decision-making responsibilities. This is particularly relevant when the Oversight Board is different from the body charged with (an)other decision-making responsibility(ies). ${ }^{38}$ To fully grasp the exact scope of Board oversight, we need to describe its interaction with the other decision-making responsibilities.

\section{Interaction with Executive Management}

45. Given that executive management controls how the financial resources and operations of a central bank are being used, Board oversight should focus its attention on this decision-making responsibility. In particular, oversight should ascertain that the body charged with executive management exercises its decision-making powers appropriately and within the confinements of the organization's strategies and its general internal policies. These policies formulated by the Oversight Board are binding upon executive management. Internal policies will also guide the Oversight Body by setting benchmarks against which the performance of executive management can be checked.

46. At the same time, the Oversight Board should not meddle inappropriately with, and try to micro-manage, executive management. ${ }^{39}$ In doing so, the Oversight Board would not remain sufficiently distant from the executive management it is required to oversee, which could severely hamper the Oversight Board's autonomy from executive management.

\section{Interaction with Public Policy Formulation}

47. The interaction with public policy formulation is a delicate one and reflects a complex relationship of "checks and balances." Board oversight should not constrain, or superpose itself on, public policy formulation. (In para. 67 below, we discuss what this requires from the perspective of legal drafting.) This is explained by the specific nature of central banks: the responsibility to formulate public policy will be allocated by law to the most competent decisionmaking body. It would make little sense to entrust another decision-making body of the central bank with the task to oversee this activity through binding general and specific decisions, as this would by definition require an almost equal level of expertise and would inevitably result in "second guessing." Moreover, the central bank will be accountable for its policy formulating decisions toward the State institutions through external oversight. This being said, the Oversight Board can interact with the decision-making body entrusted with public policy formulation (if different) at two levels:

- $\quad$ First, as part of the broader checks and balances between decision-making bodies, the Oversight Board should be in a position to exercise adequate oversight over the relevant

\footnotetext{
${ }^{38}$ In case the same body is entrusted with oversight, public policy formulation and regulatory decision-making, that body should be able to balance those decision-making responsibilities.

${ }^{39}$ For a more general discussion of this topic: see Faleye, O., Hoitash, R., and Hoitash, U., The Trouble with Too Much Board Oversight, MIT Sloan Management Review, 2013, Nr. 3p. 53-56.
} 
aspects that flow from the public policy choices, for instance by ensuring that (i) the financial statements give a fair and true view of the financial situation of the central bank, (ii) risk management and internal controls with regard to the management of the official foreign reserves are in line with the size and complexity of the total portfolio of those assets, and (iii) own funds of the central bank are sufficient to mitigate the financial risk incurred.

- $\quad$ Second, there are central banks laws that entrust some form of "monitoring" responsibility over policy formulation to the Oversight Board..$^{40}$ But upon a close look, this responsibility lacks general and specific decisions that bind the competent decisionmaking bodies, which explains our hesitation to label it as "oversight." $\mathbf{4 1}$

\section{Interaction with Regulatory Decision-Making}

48. The same principles apply with respect to regulatory decision-making. Board oversight should not constrain, or superpose itself on, this decision-making responsibility. However, the Oversight Board can exercise adequate oversight over the relevant aspects that flow from the regulatory decision-making (for instance by provisioning for litigation costs stemming from challenges to regulatory decisions) and monitor broad regulatory developments.

\section{B. To whom the Oversight responsibility is entrusted: the Oversight Board}

49. Pursuant to the general legal principle of "No Gaps No Overlaps," every central bank should have an internal decision-making body entrusted with exercising the oversight decisionmaking responsibility within the institution. This body should be appropriately designed and be different and sufficiently independent from executive management.

50. There are four reasons why the oversight responsibility should be allocated to an internal body of the central bank. ${ }^{42}$

\footnotetext{
${ }^{40}$ In Belgium, Article 20 of the Organic Law of the National Bank of Belgium gives the Council of Regency the power to "exchange views on general issues relating to the Bank, monetary policy and the economic situation of the country (...) supervisory policy with regard to each of the sectors subject to the Bank's supervision, (...), as well as, in general, any development concerning the financial system subject to the Bank's supervision; without however having any competence to intervene at operational level or take note of individual dossiers." In New Zealand, Section 53.1(a) of the Reserve Bank of New Zealand Act charges the Board of Directors to "keep under constant review the performance of the Bank in carrying out" its monetary policy functions and its functions relating to promoting the maintenance of a sound and efficient financial system." The italicized language indicates that this amounts more to monitoring than to oversight as defined by this paper.

${ }^{41}$ BIS, o.c., p. 82-83 takes the approach that "supervisory responsibilities" could extend to policy formulation, but we note the definitional difference between the paper and this document.

42 The theoretical arguments that could be invoked to support entrusting the oversight responsibility to an external body (e.g., a "Council" composed of ministers and high-raking civil servants) are that such an external body (a) has broader views, (b) is a better remedy to groupthink, and (c) is a more effective tool to ensure
} 
i. Having an internal oversight body aligns the incentives towards the institutional goals of the organisation and avoids potential conflicts of interest stemming from the pursuit of other ends that are not in the best interest of the central bank. From a legal perspective, an external Oversight body might not exclusively be committed to the objectives of the central bank. ${ }^{43}$ An external Oversight body might have different priorities and even the obligation to take decisions potentially inconsistent with the objectives of the central bank. This point is all the more relevant because the role of Oversight Boards is not limited to supervising the central bank's executive management, but also includes formulating internal policies, thus influencing the performance of all institutional activities.

ii. As previously discussed, in the absence of an internal decision-making body, external political bodies will be inclined to fill this vacuum by exercising oversight. However, these external bodies are likely to have (i) less relevant skills and inside knowledge of how central banks operate; and (ii) a higher tendency to impede the autonomy of the central bank for political reasons.

iii. Allocating the oversight responsibility to an internal body reinforces the checks and balances within-as opposed to: from outside - the central bank, thus contributing generally to robust governance.

iv. Central banks should lead by example vis-à-vis supervised financial institutions. International standards requires banking supervisory institutions-many of which are central banks - to impose upon supervised banks robust governance arrangements, including strong Oversight Boards charged with holding executive management accountable and with the final responsibility over internal controls. ${ }^{44}$ If central banks want to be effective in imposing such a standard on supervised financial institutions, they will need to show that they themselves are capable of adhering to a similar level of quality in their internal governance. ${ }^{45}$

51. This brings us to an important question of this paper: Do all central banks have an Oversight Board? To be able to respond to that question, we need to explore what forms such an Oversight Board could take, and next survey the practice of the IMF membership.

52. Typically, the form which central bank Oversight Boards take is determined by the legal history of central banks, and in particular the early interaction of central bank law with company

\footnotetext{
coordination with broader Government. These are not strong arguments, as (a) and (b) can be achieved through sound eligibility criteria, while (c) is not related to oversight but concerns policy formulation.

${ }^{43}$ The point is well established in corporate law: the directors of a company owe a duty of loyalty or fiduciary duty first and foremost to the company 6.

44 The Basel Core Principles for Effective Banking Supervision, in their Core Principle 14, Essential Criteria 5 \& 6 , require the following: "The supervisor determines that the bank's Board (...) establishes a strong control environment." and "The supervisor determines that the bank's Board (...) actively and critically oversees senior management's execution of Board strategies, including monitoring senior management's performance against standards established for them."

${ }^{45}$ However, the comparative analysis displayed in part IV of this publication shows that, with regards to the chair of their Oversight Boards in particular, central banks do not always lead by example.
} 
law. While the first central banks (the Amsterdamse Wisselbank, the Swedish Riksbank and the Bank of England) were created in the $17^{\text {th }}$ century, ${ }^{46}$ the dawn of central banks was in the $19^{\text {th }}$ century (see Figure 7).

Figure 7. Dates of Establishment of Central Banks ${ }^{47}$

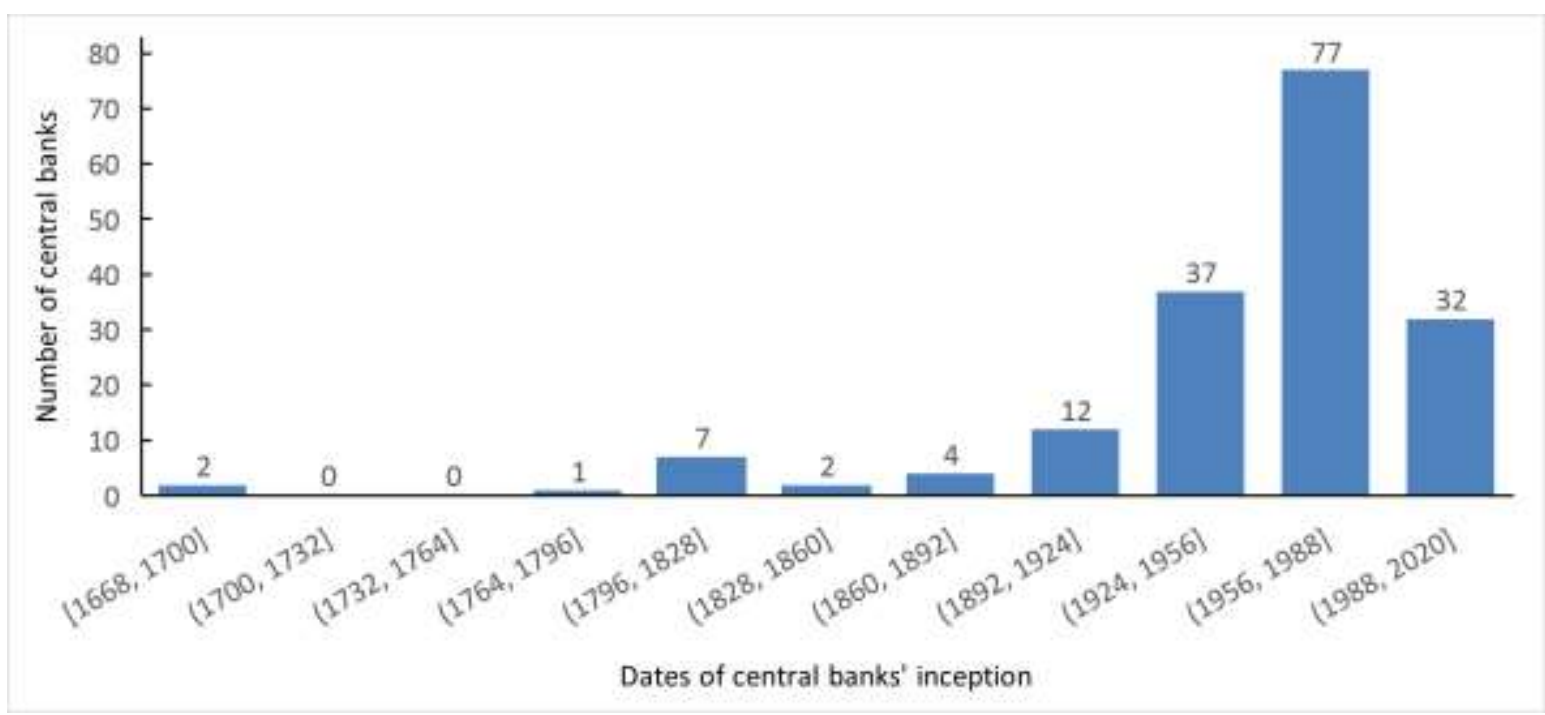

Source: IMF staff.

During that period, almost all central banks were established by the State, by or pursuant to their Organic Laws, but in the form of companies, owned by private shareholders and at least partially governed by company law ${ }^{48}$. Their corporate form also gave those central banks the typical corporate decision-making bodies, such as a general assembly of shareholders, a Board of Directors/Supervisory Board, and a body entrusted with executive management (the Governor as Chief Executive Officer or an Executive Board). As per general rules of company law, it was the

\footnotetext{
${ }^{46}$ Determining the first central bank is a complicated exercise as "defining central banking is problematic. In one sense we recognize it when we see it": see Capie, F. Goodhart, C. and Schnadt, N., o.c., 1994 p. 5. Some scholars have argued that the first central bank is the Amsterdamse Wisselbank. See Quinn, S. and Roberds, W. An Economic Explanation of the Early Bank of Amsterdam, Debasement, Bills of Exchange, and the Emergence of the First Central Bank, 2006. However, the Amsterdamse Wisselbank itself was modeled on older institutions that some have called "Public Banks" including the Venetian Banco di Rialto (1587) and the Banco di San Giorgio (1408). See Roberds, W. and Velde, F. Early Public Banks, 2014. See also, Andersen S. The Origins and Nature of Scandinavian Central Banking, 2016, p.27.

${ }^{47}$ To create this histogram, we used the 2016 Central Bank Directory with a few modifications, e.g excluding nonmembers of the IMF. Also, the chart reflects the date of creation of continually existing central banks. For discontinued predecessors to modern central banks, see Capie, F. Goodhart C. and Schnadt, N., o.c., 1994 Appendix B, A short history of central bank objectives and functions.

${ }^{48}$ The Bank of England, established in 1694 as a corporation with special privileges, had 1272 shareholders who raised $£ 1.2$ million in capital to help the government of William III rebuild its navy after a naval defeat against France. A minimum of $£ 500$ was required for voting privileges, $£ 2,000$ was required to become a director and $£ 4,000$ to become governor. See Capie, F. and Wood, G. The Governance of Central Banks: With Some Examples and Some Implications for All, in the Oxford Handbook of the Economics of Central Banking.
} 
Board of Directors/Supervisory Board and the general assembly of shareholders that exercised oversight over executive management. After the Great Depression and World War II, new central banks were established (including in newly established countries during the decolonization) as State-owned and public law entities, while the older central banks were, to a large extent, nationalized. ${ }^{49}$ Even though the newly created central banks did not have a corporate form, they kept two of the three corporate bodies, namely the Board of Directors/Supervisory Board, and a body entrusted with executive management. There was no longer a need to have a general assembly of shareholders, as there was only one shareholder (the State). For those modern central banks, the Board of Directors/Supervisory Board was the one and only body entrusted with oversight responsibilities. This historic development is summarized in the following table (Table 2).

Table 2. From Corporate Law Central Banks to Public Law Central Banks

\begin{tabular}{|l|l|l|}
\hline & $1668-1945$ & 1945 - Today \\
\hline Owners & Private & State \\
\hline Legal Form & $\begin{array}{l}\text { "Societe anonyme" } \\
\text { Public Law Company }\end{array}$ & Public Law Entity \\
\hline $\begin{array}{l}\text { Legal } \\
\text { Instruments }\end{array}$ & $\begin{array}{l}\text { Organic Law } \\
\text { Company Law } \\
\text { By-Laws }\end{array}$ & Organic law \\
\hline $\begin{array}{l}\text { Decision- } \\
\text { Making } \\
\text { Bodies }\end{array}$ & $\begin{array}{l}\text { CEO ("Governor")/Executive Board } \\
\text { Board of Directors/Supervisory } \\
\text { Board } \\
\text { General Assembly of Shareholders }\end{array}$ & $\begin{array}{l}\text { CEO ("Governor")/Executive Board } \\
\text { Board of Directors/Supervisory } \\
\text { Board } \\
\text { (Policy Formulation Committee) }\end{array}$ \\
\hline
\end{tabular}

Source: IMF staff.

53. Thus, in line with broader company law traditions, the Oversight Boards of central banks can take a form following either of two models.

- $\quad$ Boards of Directors -This type of Board, which stems from the Franco-British legal tradition, combines non-executive and executive directors (on the difference between the two: see para 74, third bullet), and can be chaired by either. In central banks, such Boards often combine oversight with other decision-making responsibilities, namely policy formulation and regulatory decision-making. For the purpose of this paper, Boards that are composed only of executives also fall in that category. Hence, there are 3 types of Boards of Directors:

\footnotetext{
${ }^{49}$ Countries with central banks that still have private shareholders include Belgium, Greece, Italy, Japan, South Africa, Switzerland, Turkey and the USA, (for the 12 Federal Reserve Banks; not the Board of Governors).
} 
(i) Boards of Directors with a majority of non-executives and a minority of executive members;

(ii) Boards of Directors with a majority of executives and a minority of nonexecutive members; and

(iii) Boards of Directors composed only of executives.

- $\quad$ Supervisory Boards-This type of Board, which stems from the Germanic company law tradition (with the Aufsichtsrat), is composed of non-executive members only, has by consequence a non-executive chair, and is only charged with oversight. ${ }^{50}$ Even though such Boards are entirely composed on non-executives, they are internal to the central bank, in the sense that they are unequivocally decision-making bodies ("organs") of the central bank.

The fundamental distinction between these two types of Boards is summarized in the following table (Table 3).

Table 3. Boards of Directors v. Supervisory Boards

\begin{tabular}{|l|l|}
\hline Board of Directors & Supervisory Boards \\
\hline $\begin{array}{l}\text { Combines executive and non-executive } \\
\text { "directors" }\end{array}$ & Includes only non-executive "members" \\
\hline $\begin{array}{l}\text { Can be chaired by executive or non- } \\
\text { executive }\end{array}$ & Chaired by non-executive \\
\hline $\begin{array}{l}\text { Combines oversight with other decision- } \\
\text { making responsibilities (policy-making } \\
\text { and/or regulatory) }\end{array}$ & Charged exclusively with oversight \\
\hline $\begin{array}{l}\text { French and British corporate and central } \\
\text { banking tradition }\end{array}$ & $\begin{array}{l}\text { Germanic corporate and central banking } \\
\text { tradition }\end{array}$ \\
\hline
\end{tabular}

Source: IMF staff.

The definitional distinction between the two types of Board is very important for the remainder of the paper, as some important legal design variables discussed below only apply to Boards of Directors and not to Supervisory Boards (as defined).

\footnotetext{
${ }^{50} \mathrm{BIS}$, o.c., p. 82 takes another position but this is explained by definitional differences between this paper and the BIS document. The BIS defines "Supervisory Boards" as the "internal oversight board" (see footnote 80).
} 
54. In the corporate governance literature, Oversight Boards are often categorized in function of the type of executive management they are called upon to oversee. ${ }^{51}$ Supervisory Boards are said to operate in a "dual board" structure, because under the Germanic corporate model they oversee collegial executive management in the form of Executive Boards (the famous German Vorstand), which are entirely distinct in their membership from the Supervisory Boards. In contrast, Boards of Directors are often labelled "single" or "unitary" boards, because they oversee executive management concentrated in one individual (CEO or Governor, who is typically part of the Board), and hence the Board is a "single" Board. ${ }^{52}$

55. However relevant this distinction is under corporate law, ${ }^{53}$ in respect of central banks it is not absolute. For instance, there are a number of central banks where Boards of Directors oversee Executive Boards; this is a hybrid model. ${ }^{54}$ Also, there are at least two central banks where a Supervisory Board oversees a single Governor. ${ }^{55}$ The various possible relationships between a central bank's Oversight Board and executive management are summarized in the following figure:

\footnotetext{
${ }^{51}$ E.g., see Kraakman, R et al. The Anatomy of Corporate Law: A Comparative and Functional Approach in Chapter IV The Basic Governance Structure: The Interests of Shareholders as a Class, Oxford University Press, 2017.

52 This does not preclude the establishment of Executive Committees or similar collegial management bodies in central banks with one-tier Board structures. However, as these collegial management bodies' authority stems from the delegation of part of the Governor's executive management responsibilities, the Governor is still the ultimate decision maker in this respect and so such models qualify as one-tier Board structures and not hybrid board structures in this paper.

53 Even under company law, the traditional approaches and divisions are less and less Cartesian. For instance, French company law allows certain companies to adopt the Germanic governance model (Art. L225-57 of the Code de Commerce), with an Executive Board (Art. L225-58) and Supervisory Board (Art. L225-68), with the strictest separation between the two (Art. L225-74). Under the previous Belgian company law, certain types of companies can combine an Executive Board and a Board of Directors, with members of the former sitting on the latter (Art. 524bis of the Companies Code), thus echoing the governance of the central bank (see next footnote). The current Belgian company law follows the French model as it allows to adopt a fully Germanic approach.

${ }^{54}$ E.g. the National Bank of Belgium's Council of Regents combines 10 non-executive Regents and all 6 members of the Executive Board. The Supervisory Board of the National Bank of Moldova includes 4 non-executives and 3 executives. The latter are part of a 5-member Executive Board.

55 This is the case of Iceland and Suriname.
} 
Figure 8. Oversight Boards and Executive Management in Central Banks ${ }^{56}$

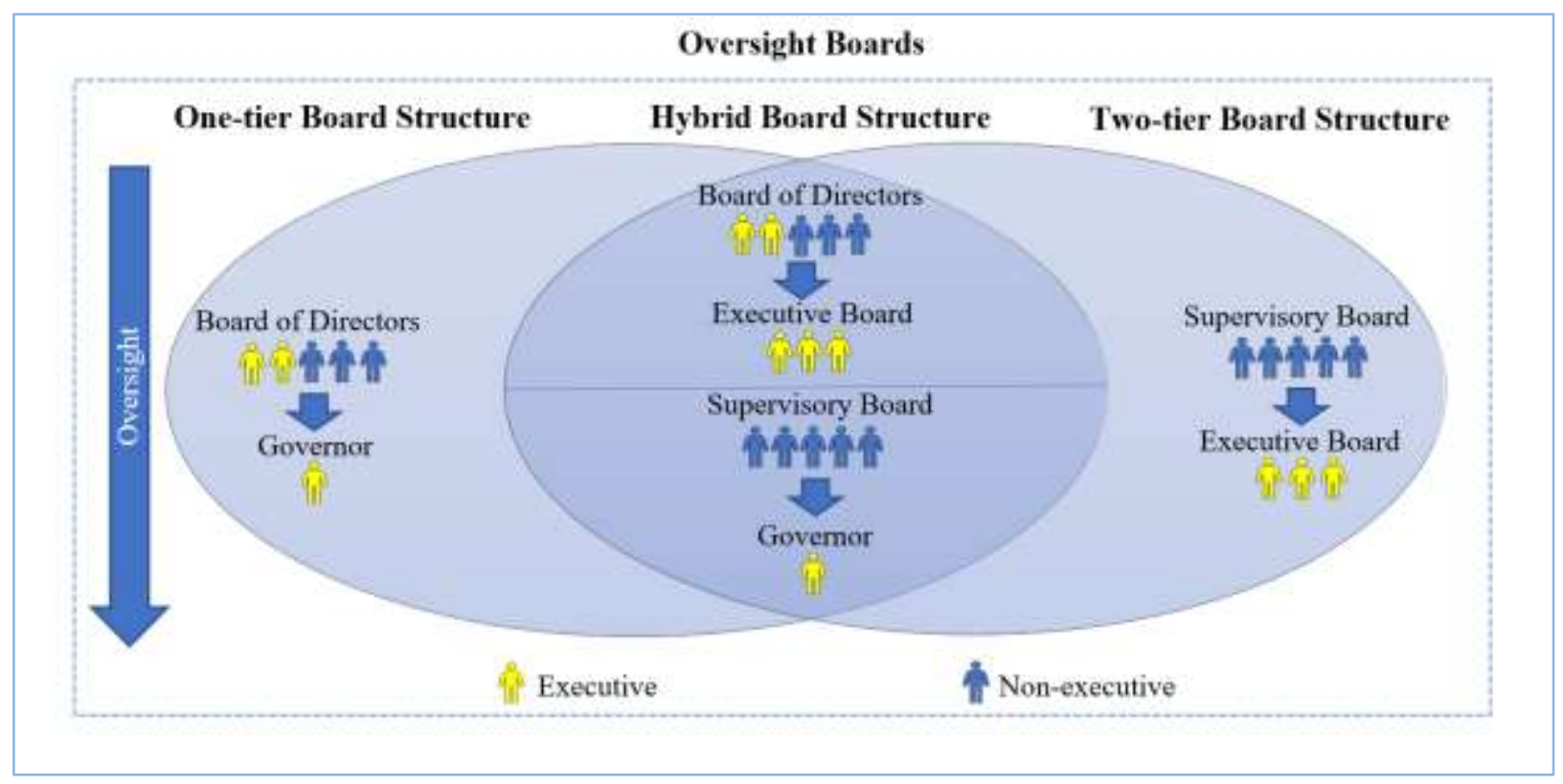

Source: IMF staff.

56. For the purpose of categorization in this paper, the composition of the central bank Board is decisive, and not the formal label.

- We use the term "Board of Directors" for any type of Oversight Board that combines executive and non-executive members, regardless of its name. We do not use the term unitary board, for the reason explained above, that some Board of Directors actually operate in a dual board structure.

- $\quad$ Similarly, we use the term Supervisory Board for Oversight Boards that are exclusively composed of non-executives, also regardless of its name.

We note that there are central bank laws that label the Oversight Board as a "Board of Directors," even though the latter really is a Supervisory Board. ${ }^{57}$ Conversely, there are central bank laws that establish a "Supervisory Board" that really is a Board of Directors. ${ }^{58}$

57. The vast majority of central banks around the world have some form of Oversight Board as defined by the paper: of 174 central banks surveyed, only 4 have no such Board. ${ }^{59}$ As

\footnotetext{
${ }^{56}$ Note that the size of the Boards depicted in the figure is provided for representation purpose only as Executive Boards typically have 4 to 8 members while most of the Supervisory Boards and Boards of Directors have respectively 5 and 7 members (see Box 3).

57 This is the cases of the BEAC and the central banks of Comoros and Denmark.

${ }^{58}$ For instance, in Albania the "Supervisory Council" of the central bank.

${ }^{59}$ We note that this conclusion differs from the one of the BIS, o.C., p. 82. This is explained by the definitional difference of Oversight Boards between this paper and the BIS document. While the former includes Boards with
} 
illustrated by (Figure 9) below, 12\% (20) of central banks' Oversight Boards consist of a Supervisory Board-type of structure, whereas 88\% (150) of a Board of Directors-type of structure. The dominance of the latter model is largely explained by the influence of the English-French central banking model in the decolonization.

Figure 9. Types of Oversight Boards and Monetary Policy Responsibilities

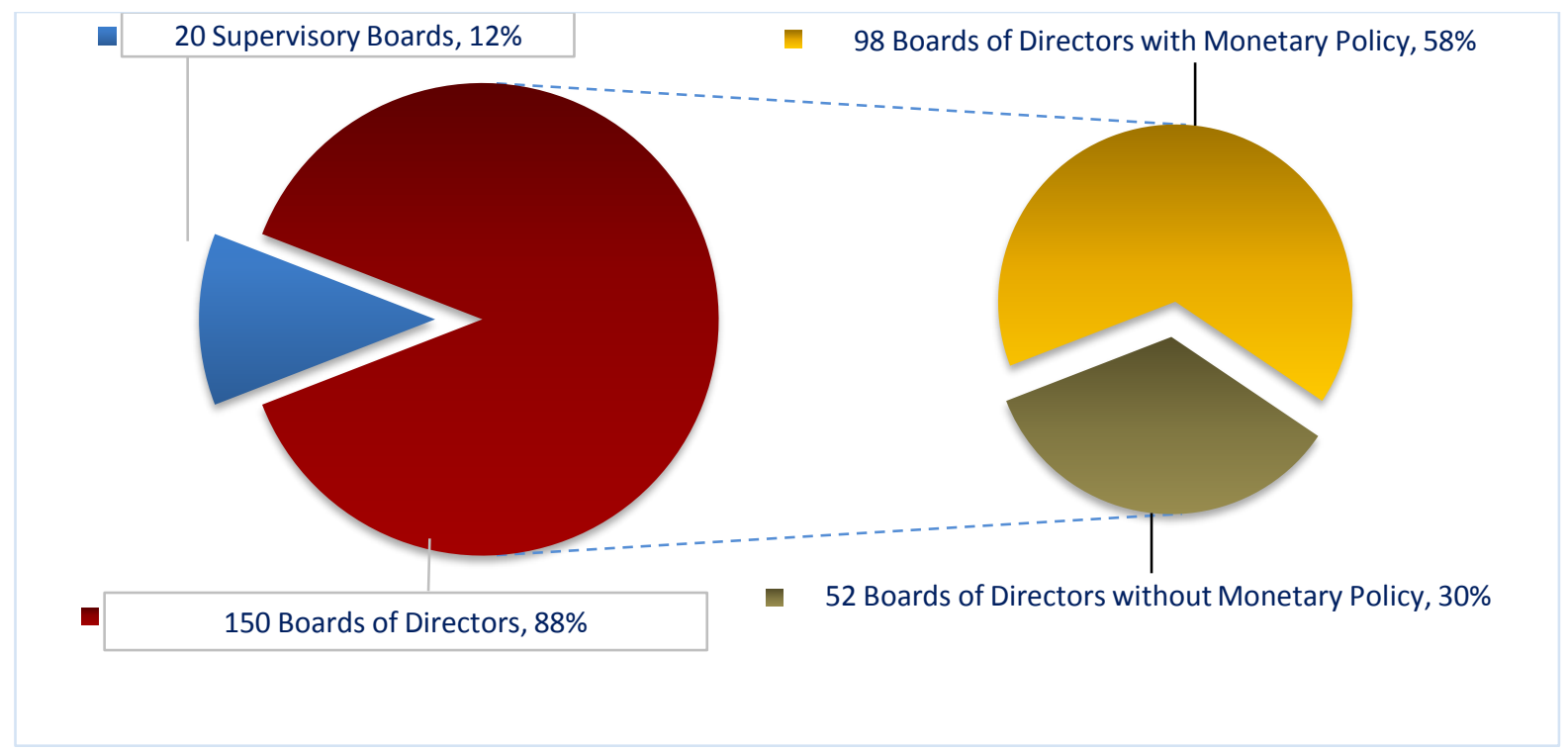

Source: IMF staff.

58. Not all Oversight Boards focus exclusively, or even primarily, on oversight. Historically, central bank Boards of Directors would often be entrusted with 3 of the 4 decision-making responsibilities: (i) oversight, (ii) public policy formulation; and (iii) regulatory decision-making. ${ }^{60}$ Following the example of the Bank of England, there has been a recent trend, as part of a broader endeavor to increase autonomy, to shift monetary policy formulation away to a specialized committee that is fully vested with the power to take monetary policy decisions. ${ }^{61}$ However, Figure 9 illustrates that a majority (58\%) of the surveyed central banks' Oversight Boards continue to combine oversight and monetary policy formulation responsibilities. As will be discussed in the next section, this has a significant impact on some critical legal design variables of Oversight Boards.

some oversight responsibilities (in line with Lybek and Morris, o.c.), the latter only includes Boards having a prominent supervisory role.

60 Interestingly, there is one "supervisory board" (as defined in this paper-the body is however labelled "board of directors") among the whole membership that is also entrusted with monetary policy formulation, namely in the Comoros. This exception is not reflected in Figure 8.

${ }^{61}$ In fact, there exist two types of Monetary Policy Committees. The first type is the Bank of England's model. The second type is an internal advisory committee to the Board of Directors which maintains the ultimate responsibility for monetary policy decisions. 


\section{How Board Oversight is conducted: Oversight Procedures}

59. As with all decision-making responsibilities, Board oversight is exercised through a set of procedures. These procedures will specify critical details of how the oversight is implemented, e.g. how regularly the Oversight Board meets, who sets its agenda, and how it takes decisions. Procedural rules may also specify how the entire Oversight Board interacts with its specialized committees, in particular the Audit Committee. In designing legal frameworks for central banks, the procedural aspect of decision-making is sometimes ignored relative to the establishment of the decision-making bodies. This is a mistake, as without robust procedural rules, Board oversight will struggle to be effective.

\section{Legal Design ISSUES}

60. This section will discuss some key issues pertaining to the legal design of (a) Board oversight responsibilities, (b) the composition of the Oversight Board, and (c) procedural aspects of Board oversight within central banks.

\section{A. Oversight Responsibilities (the "What?")}

61. Issue-The capability of the Oversight Board to oversee executive management depends upon the adequacy, exhaustiveness, clarity and precision with which its oversight responsibilities are legally established and defined in the central bank law. ${ }^{62} \mathrm{~A}$ lack of legal empowerment to oversee executive management is an obstacle to robust and effective oversight. In the absence of a legally robust empowerment, executive management can challenge attempts to establish effective oversight, including the very legitimacy of the Oversight Board in its endeavors, even though Oversight Boards are, more often than not, made the supreme decision-making body ${ }^{63}$ of their institution by their organic law. ${ }^{64}$ This holds all the more true if the legal design of the Oversight Board and oversight procedures is suboptimal.

62. In many central bank laws, the legal formulation of the Oversight Board's oversight responsibilities leaves something to be desired. One problem is that the central bank law only makes a general statement. For instance, the Board "will administer the central bank" or is responsible for setting the "strategic planning" of the central bank. These general statements are

\footnotetext{
${ }^{62}$ While it is impossible to draft a perfect legal delineation between oversight and executive management, it will be important to distinguish as well as possible between the two responsibilities. In the absence of clarity, executive management could not only challenge the range of oversight powers of the Oversight Board, but also undermine that oversight by making the Board "complicit" in the decisions within the remit of executive management, thus sharing responsibility with that body.

${ }^{63}$ In the rare cases of central banks that still have a general assembly of shareholders, the latter will be the supreme decision-making bodies of their respective central bank. See Aufricht, H. Central Banking Legislation, IMF, 1961, p. 40.

${ }^{64}$ This problem is exacerbated when, as often is the case, the body charged with the executive management responsibility is also granted the residual powers (as explained in para. 27): in such case, the Oversight Board is only competent for those powers explicitly allocated to it by the central bank law.
} 
not strong enough an empowerment to oversee executive management. A second common problem is that the enumeration of the specific oversight decision-making powers is too narrow and limited to a small number of decisions, such as the approval of the annual financial statements or the appointment of the external auditors of the central bank. A third issue is that the Oversight Board itself is not the only decision-making body competent to decide on the entirety of the core decision-making powers that are necessary to conduct effective oversight. In other words, a decision-making body (typically executive management) different from the Oversight Board may be competent for some oversight-related decision-making powers (e.g. approval of financial statements).

63. Staff's Advisory Practice-Fund staff advizes that the robust legal definition of the oversight responsibility of the Oversight Board is best achieved through a combination of three legislative drafting techniques.

64. First, a strong and explicit general statement should be included in the central bank law that the Oversight Board is responsible for overseeing executive management. The advantage of such a general statement is that it leaves no doubt that this is a core responsibility of the Oversight Board and that the latter is responsible and accountable for a failing oversight. As a minimum, the general statement should be drafted from the perspective of the Oversight Board itself, i.e. listing oversight over executive management as an explicit responsibility of the Oversight Board. Furthermore, this could usefully be complemented with legislative provisions that require executive management to take their executive decisions within the frameworks and policies adopted by the Oversight Board. This statement could also be complemented with a general duty for the Oversight Board to verify that the central bank is discharging its functions in accordance with the internal organizational policies and frameworks determined by the Oversight Board.

65. Secondly, the central bank law should include a comprehensive listing ${ }^{65}$ of the relevant oversight-related decision-making powers of the Oversight Board. Based upon the discussion above (see para. 42 and Table 1), this listing should cover both:

- General powers to formulate the internal organizational policies as well as the issuance of internal regulations and other legal instruments relevant to the sound administration of the central bank (such as on accounting, audit, risk management, human resources, etc); ${ }^{66}$ and

\footnotetext{
${ }^{65} \mathrm{~A}$ "listing" does not entail that all oversight powers must be literally listed in a single legislative provision: while there is certainly a benefit in terms of transparency to this, from a formal perspective having powers dispersed over a number of legislative provisions can equally be appropriate.

${ }^{66}$ On external audit, see: Arda, A., Gororo, M., Grochalska, J., and Mohlala, M., External Audit Arrangements at Central Banks, IMF, WP/18/199.
} 
- $\quad$ Specific decision-making powers that will allow the Oversight Board to operate as an effective check on executive management (such as approval of budget and financial statements, appointment of external auditors and chief internal auditor ${ }^{67}$ ).

66. Third, unless this is dealt with otherwise (e.g., through application of general principles), the central bank law should include explicit prescriptions on the provision of information to the

Oversight Board. Specifically, legislative provisions could require executive management:

i. to report regularly ${ }^{68}$ to the Oversight Board on the delivery of its executive tasks as well as on the occurrences that have a significant effect on the administration or operations of the central bank;

ii. to provide the Oversight Board with all information which the latter deems necessary for a proper exercise of its duties (but not beyond what is appropriate, in the sense that the Oversight Board should not have access to confidential information e.g. related to microprudential supervision).

Box 1 below gives examples of well-drafted central bank law provisions that grant some of those powers to the central bank

\footnotetext{
${ }^{67}$ Other specific decision-making powers that could allow the Oversight Board to operate as an effective check on executive management include powers: (i) to set the remuneration and other benefits paid to the executive management, (ii) to open and close branches of the central bank and decide on the overall structure of the bank, (iii) to have the final say on the buying and renting of the premises used by central bank staff, (iv) the ability to direct the auditors to enquire on areas that the Board mandates, and ( $v$ ) the ability of the Board to set its own internal rules of procedure further specifying how it will oversee management.

${ }^{68}$ For example, in the case of the Central Bank of Bosnia and Herzegovina it is foreseen in the central bank law (Article 6.2) that the management of the Central Bank shall report, not less than once every month, to the Governing Board on the administration and operations of the Central Bank.
} 


\section{Box 1. Examples of Well-Drafted Oversight Responsibilities}

\section{Norges Bank}

Section 5 of the law on the Norges Bank is a good example of a strong and explicit general statement that the Oversight Board is responsible for overseeing executive management: "The Supervisory Council shall in this respect supervise the Executive Board to ensure that the Executive Board's management and control of the Bank's administration and operations are satisfactory and that appropriate procedures have been established so that the Bank's activities are conducted in accordance with legislation, agreements, decisions and other regulatory frameworks. (...) The Supervisory Council has the right of access with respect to all of the Bank's affairs and may conduct any investigations it deems necessary in order to fulfil its responsibilities under the Act."

\section{BEAC}

Article 32 of the Charter of the Banque des Etats de l'Afrique Centrale (BEAC) - a central bank that recently underwent very significative governance reforms-is another good example of well-drafted oversight powers: it lists quite exhaustively the general decision-making power to formulate internal policies and specific decision-making powers through which the oversight is operationalized.

\section{Oversight Policies}

- $\quad$ Art. 32.3 provides that the Board of Directors adopts policies on internal and external audit, compliance and risk management, and oversees the implementation of those policies;

- $\quad$ Art. 32.4 charges the Board of Directors with the control, including internal controls of the central bank, with assistance of the Audit Committee;

- $\quad$ Art. 32.6 empowers the Board of Directors to adopt the financial reporting framework and implementing measures; and

- $\quad$ Art. 32.20 authorizes the Board of Directors to approve the investment and risk policies for the Official Foreign Reserves.

\section{Oversight Decisions}

- $\quad$ Art. 32.7 empowers the Board of Directors to adopt the budget of the central bank and to oversee its execution, with assistance of the College of Censors;

- $\quad$ Per Art. 32.8-9, the Board of Directors adopts the annual financial statements and the annual report;

- $\quad$ Art. 32.18 gives the Board of Directors the power to approve any agreement that goes beyond day-to-day management; and

- $\quad$ The external auditors are appointed by the Board of Directors (Art. 69). 
67. While the legal formulation of the oversight responsibilities must be robust, it must at the same time also be circumscribed. In particular, care must be taken not to hinder the public policy formulation responsibility of the central bank by an excessively wide definition of oversight powers. This is particularly important when a central bank law has entrusted public policy formulation responsibilities to another body than the Oversight Board. (In case of a Board of Directors combining both responsibilities, the issue is less salient, as the Board can arbitrate between its public policy formulation and oversight responsibilities.) At the same time, the Oversight Board should be in a position to exercise adequate oversight on the relevant aspects that flow from the public policy choices. While it is not always easy to distinguish in all cases between the two decision-making responsibilities, some legislative frameworks have succeeded in making a distinction between the two, ensuring that public policy formulation is not hampered by oversight. ${ }^{69}$ As a legal matter, this is achieved by a combination of two legal techniques, namely (a) limiting the specific oversight powers to the aspects enumerated in Table 1, and (b) where a conflict with policy formulation could occur, clarifying that policy formulation takes precedence over the oversight decisions.

\section{B. Oversight Boards (the "Who?")}

68. This subsection will discuss in detail four legal design variables of Oversight Boards that have a critical impact on the capability to exercise effective oversight, namely:

i. The requirement of a non-executive majority of Oversight Board members;

ii. The chair of the Oversight Board;

iii. The presence of Public Sector Board members; and

iv. The role of eligibility criteria for non-executive Board members.

For each of the variables, we will explain the key legal issue, give an overview of country practice, and summarize staff's advisory practice towards member countries.

\section{Majority of Non-Executive Board Members}

69. Issue-Given that a core purpose of a central bank's Oversight Board is to oversee executive management, it is imperative that the Oversight Board is sufficiently autonomous from executive management. Thus, the executives (Governor, Deputy-Governors, and Executive Directors) of the central bank should not control or otherwise dominate the Oversight Board. Up front, we must remind ourselves that this is not a problem with Supervisory Boards, as these

\footnotetext{
${ }^{69}$ The Charter of the BEAC is a good example of this point. Art. 38.1 stipulates that the Monetary Policy Committee defines the monetary policy of the central bank as well as "the major directives of pursued level and structure of the official foreign reserves, in line with macro-economic objectives." In turn, Art. 32.20 entrust the Board of Directors - the Oversight Board of the BEAC — with formulating the investment and risk management policies for the official foreign reserves, "in conformity with the directives of the Monetary Policy Committee." Art. 20 of the Organic Law of the National Bank of Belgium mentioned in footnote 39 is another good example.
} 
bodies are inherently composed of non-executive members only. The problem arises, however, in respect of Boards of Directors, which combine executive and non-executive members, and in some cases are even composed exclusively of executives (see below).

70. Defining the exact difference between executives and non-executive Directors is not always easy (see para. 74 below). We consider the latter to be the central bank equivalent of the "outside directors" as defined in Black's Law Dictionary as "a member of a corporate board of directors who is not a company officer and does not participate in the corporation's day-to-day management." ${ }^{\prime 70}$

71. The concept of a non-executive directors must also be distinguished from that of independent directors. Whereas the adjective "non-executive" relates to the relationship between a director and executive management, the term "independent" refers in a corporate law context to the relationship between a director and significant shareholders. In the context of Stateowned central banks, the latter concept has no practical relevance as all directors, with the possible exception of Public Sector directors (see para. 88 et. seq.), should all be equally "personally" autonomous from the State.

72. The main legal mechanism through which the autonomy of the Board of Directors from executive management is achieved is by a legal requirement that the Board of Directors be composed of a majority of non-executive Directors. ${ }^{71}$ This is because the decisions, which Oversight Boards take, are typically adopted by the majority of the members present at meetings where the Board is to decide on the issue. ${ }^{72}$

73. Other legal mechanisms and governance principles are also relevant to ensure that the non-executive members of Oversight Boards are sufficiently autonomous from executive management. This paper will not discuss these mechanisms, which often pertain to the appointment and dismissal procedures. For instance, executive management should have no role (e.g., by formally proposing) in the appointment procedure of the non-executive Board members.

74. Country Practice-A survey of the central bank laws of the IMF's membership (see Figure 10), shows that many countries have made strong progress toward establishing a clear non-executive majority in the Boards of Directors of their central banks. Specifically, a

\footnotetext{
70 Black's Law Dictionary, $5^{\text {th }}$ Ed., 1983, p. 572. Similarly, the South African King III report defines in Annex 2.3 Non-executive directors negatively as "Not being involved in the management of the company".

${ }^{71}$ The question of the size of that majority is discussed in Boxes 2 and 3. Moreover, to ensure that the majority membership of non-executives also translates into an actual non-executive majority when decisions are taken, another legal mechanism comes into play: the quorum. The quorum will be discussed below under the procedural aspects (see para. 109).

72 In very few central banks, certain decisions of the Board are to be taken by a majority of all the members of the Board; and not the one of a smaller quorum, or at a qualified majority of Board members or even at the unanimity of the Boards members. Finally, in certain central banks, the Chair has the ability to veto the decisions taken by the Board and to defer either to the government or to the Board for it to reconsider the issue.
} 
significant majority (75\%) of central banks with a Board of Directors have now a non-executive majority of members. In the whole central banking community, the number of boards (Boards of Directors and Supervisory Boards) that have a non-executive majority is even higher: out of the 170 central banks that have Oversight Boards, 132 have a majority of non-executives, which corresponds to $78 \%$ of these institutions.

\section{Figure 10. Executive/Non-executive Membership of Central Bank Boards of Directors}

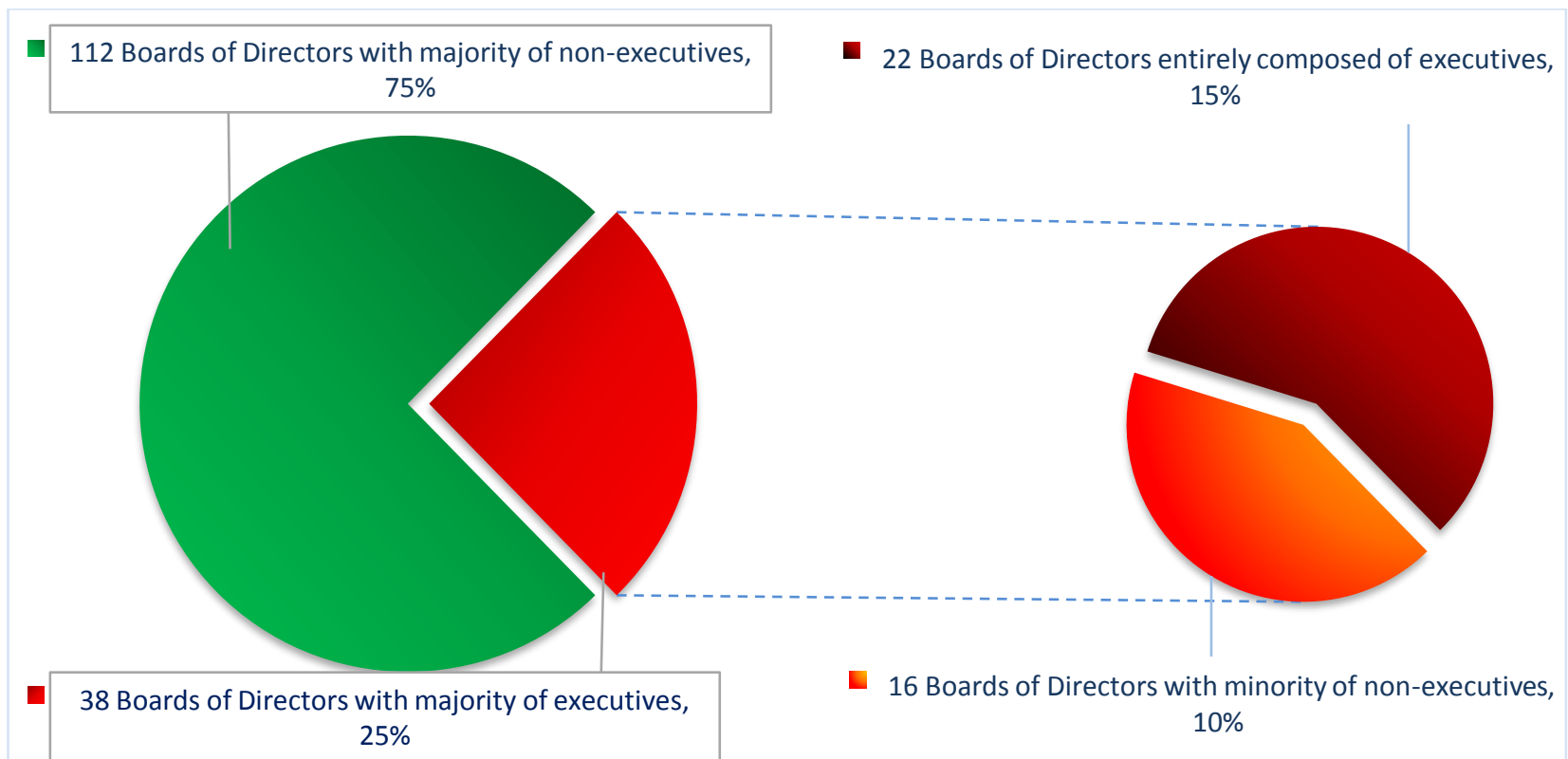

Source: IMF staff.

75. This being said, three types of problems still occur:

- $\quad$ Boards of Directors with Executive Majority-The Figure shows that there is a considerable number (38 central banks or $25 \%$ ) of central banks with a Boards of Directors that have an executive majority.

- $\quad$ Entirely Executive Boards of Directors-Some of those central banks (22, i.e. $15 \%$ of all Boards of Directors) even have an entirely executive Board of Directors! In some countries, this is not directly obvious from the central bank law itself, but it is rather an issue of actual governance practice. ${ }^{73}$

- $\quad$ Legal Uncertainty on Executive/Non-Executive Status of Directors-Several central bank laws create "Boards" that are composed of, on the one hand, Governors and Deputy Governors, and on the other hand, "Directors." Such a set-up may look like a traditional Board of Directors. A closer analysis however reveals that, while the directors do not have executive responsibilities over departments (in contrast to the Governor and Deputy-

\footnotetext{
${ }^{73}$ This set-up is most prevalent in Latin-America and in Central Asia. In Latin America, the board typically takes the name of Directorio, Junta Directiva or Junta de Gobierno. In Central Asia, these boards are mostly just labelled "Board."
} 
Governors), they are otherwise actively involved in central bank management on a (almost) daily basis. Indications that a Director is actually involved in executive management are (i) the "Board" meets very regularly, often on a weekly basis, and (ii) that the Directors are paid what basically are executive salaries. Often in these central banks, (iii) staff meets the Directors on a regular basis to discuss ongoing projects, and (iv) the Governor delegates to individual Directors a leadership role over executive assignments. Other major elements that allowed us to form an opinion as to whether such members are executives or not include $(v)$ the annual reports of central banks describing the functions that are exercised by Board members, (vi) the Board members' Curriculum Vitae and (vii) their current professional occupation(s). While not an "Executive Board" in the pure sense of the word, ${ }^{74}$ such boards are in fact "executive." This begs the fundamental question whether such a fully executive Board can be considered as a genuine Oversight Board? ${ }^{75}$

76. Regarding the numbers above, a caveat is in order. The $78 \%$ of Oversight Boards with a non-executive majority is counted based on the maximum size Oversight Boards have by law. In addition to a majority of Oversight Boards with a fixed composition, there is a considerable number of central bank laws that include one of the following six types of varying Boards' size and composition:

- $\quad$ Boards that do not have a size of membership set by law;

- $\quad$ Boards with a minimum to a maximum number of non-executives;

- $\quad$ Boards with a minimum but no maximum number of non-executive members;

- $\quad$ Boards with a maximum but no minimum number of non-executive members;

- Boards having a chair that may be either an executive or a non-executive; and

- $\quad$ Boards that do not specify the mix of executives or non-executives serving on it.

In practice, all these instances may reduce the actual percentage of Boards with a non-executive majority or make that majority much smaller than it should ideally be (see Box 3 ).

77. Staff's Advisory Practice-Fund staff strongly advocates a majority of non-executive members on Oversight Boards. ${ }^{76}$ This position has also been supported by the Fund's Executive Board, which has adopted structural conditionality under Fund-supported programs to modify the member's central bank law to provide for such a majority. ${ }^{77}$

\footnotetext{
74 In the sense that true Executive Boards operate under a Supervisory Board and as a rule do not have oversight responsibility (or if any very few). See Figure 7.

75 This does not mean however that some of such central banks do not have other, alternative internal oversight mechanisms, such as for instance the sindicos in some Latin-American central banks. Those alternative mechanisms are however not a sufficient substitute for an effective Oversight Board.

${ }^{76}$ See Lybek, T., and Morris, J., o.C., p. 40.

${ }^{77}$ As an example, see the Memorandum of Economic Financial Policies, and Technical Memorandum of Understanding dated July 23, 2017 under the Stand-By Arrangement for Iraq: "Building on the safeguards
} 
78. Where the Directors are too much involved in executive management of the central bank (see para. 74, third bullet), Fund staff has recommended two options to introduce an Oversight Board with a non-executive majority. One option is to convert the existing Board into a wellstructured Oversight Board, by requiring a majority of Directors to withdraw from executive assignments. Another option is to create a Supervisory Board above the executive "Board of Directors" (which typically does not carry that name) and to assign the oversight responsibilities to the former.

79. From a legal-technical perspective, the design of a non-executive majority should be considered in conjunction with two other legal variables, namely the size of the Board (see Box 2) and the quorum (see Box 3), as each legal variable influences the other.

Figure 11. Interaction between Size of Board, Quorum and Non-Executive Majority

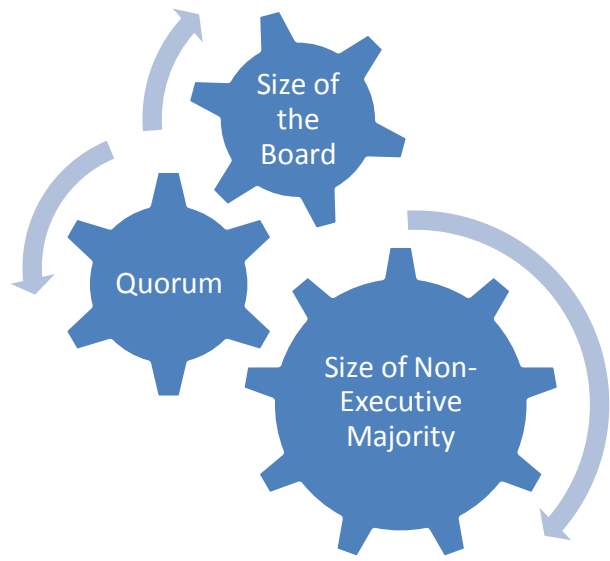

Source: IMF staff.

80. This being said, several caveats are in order. First, a majority of non-executive members on Oversight Boards is a necessary building block in the overall design of central bank decisionmaking structures; it is not a panacea for all governance problems. It is well recognized that in the realm of central banking, as in the world of private firms, effective Board oversight is more often a journey than a destination. The inherent limitations of non-executive directors (asymmetric information, less know-how) that exist in the corporate world are also valid for central banks. Through the design of legal rules, such as on access to information (para. 66) and eligibility criteria (see subsection below), these limitations can be mitigated, although never entirely removed. Giving due consideration to those caveats, non-executive members play a critical role in introducing "checks and balances" into central bank governance, and with welldesigned eligibility criteria can brings expertise (e.g., on cyber security) to the table that usefully complements that of the central bank's executive management.

assessment conducted by the IMF in December 2015, the government will continue to strengthen the legal framework of the CBI to provide for independent oversight of the CBI's operations. Specifically, the CBI Law was amended to: (...) (vi) change the CBI Board's composition to a non-executive majority." 


\section{Box 2. What is, and should be, the size of the Oversight Board?}

\section{The literature has diverging views on optimal Board size...}

Corporate governance literature is actively debating the optimal size of Boards. The literature on Boards of private firms and central banks provides the following arguments in favor of smaller or larger Oversight Boards:

Factors in favor of small Boards:

- Financial cost of having too many directors. Marginal gains in added expertise tends to be smaller as the board size increases given that individuals' participation diminishes;

- Lack of enough qualified candidates to fill positions for large boards;

- Boards are more effective in smaller settings as it is harder to coordinate a bigger board with regards to everyone's schedules or that it takes exponentially more time for the Board to take decisions as it becomes larger (Berger 2006);

- Avoids dilution of individual members' voice or responsibilities and gives Board members a greater sense of ownership and responsibility;

- Avoids the temptation from Board members to freeride on the information brought to meetings by others (Sibert); However, such behavior may be limited given that their decisions are "probably the most important things that members do in their lives." (Blinder);

- Board can dedicate more time to tackle issues in greater detail if discussing limited to a smaller number of Board members;

- Small boards are likelier to identify and act on poor performance of executive management (Lublin) and (Yermack);

- The greater the openness of the national economy the smaller the Board (Berger, Nitsch and Lybek).
Factors in favor of large Boards:

- Ensuring a diverse and informed discussion on matters stemming from inside the Bank, (e.g. presence of management and representative of employees when HR matters discussed);

- Providing informed and balanced monitoring and advising to executive management on matters typically outside the bank, including commercial, agricultural, gender, regional and sometimes ethnical issues;

- Larger Board combined with anonymous voting may provide insulation from political pressure (Berger, Nitsch and Lybek);

- The increased diversity of views brought by a larger setting may alleviate the groupthink fallacy arising in boardrooms (Colesa, Daniel and Naveen);

- Larger Boards are relatively insulated from political pressures when new board members are nominated by politicians on a staggered basis. (Nathan, A. and Groman, D.);

- The more complex the national economy or the exchange rate regime, the larger the Board as the complexity of its decisions increases, (Berger, Nitsch and Lybek);

- The more responsibilities are entrusted to the Board, the larger the Board, as its members may only be present in a certain number of Committees of the Board (Berger, Nitsch and Lybek);

- Commercial banks' board size is positively correlated with banks' performance (Adams and Mehran).

\section{...but the size suggested by authoritative authors for private firms...}

It was found-for private firms-that Boards of 8 to 9 members are most effective (Lipton and Lorsch 1992). 


\section{Box 2. What is, and should be, the size of the Oversight Board?}

(continued)

\section{...actually converges with current central bank practice}

Surveying the entire IMF membership, the current average number of members serving on Oversight Boards is 8.38, with a median of 8. Supervisory Boards are on average smaller than Boards of Directors: the biggest cohort of Boards of Directors has 7 members, while the highest percentage of Supervisory Boards has 5 members. This difference is explained by the fact that Boards of Directors often include at least two executives (the Governor and a Deputy Governor) serving next to the non-executives. Interestingly, these numbers were relatively stable over the past 20 years: Lybek, T., and Morris. J., observed in 2003 that 46 percent of the Oversight Boards had 7 to 9 members. Over a longer period of time, we observe a small decrease in size: Aufricht, $\mathrm{H}_{\text {., }}$ noted in the 1960s average and median numbers of respectively 10.94 and 9.

Number of members in Boards of Directors \& Supervisory Boards

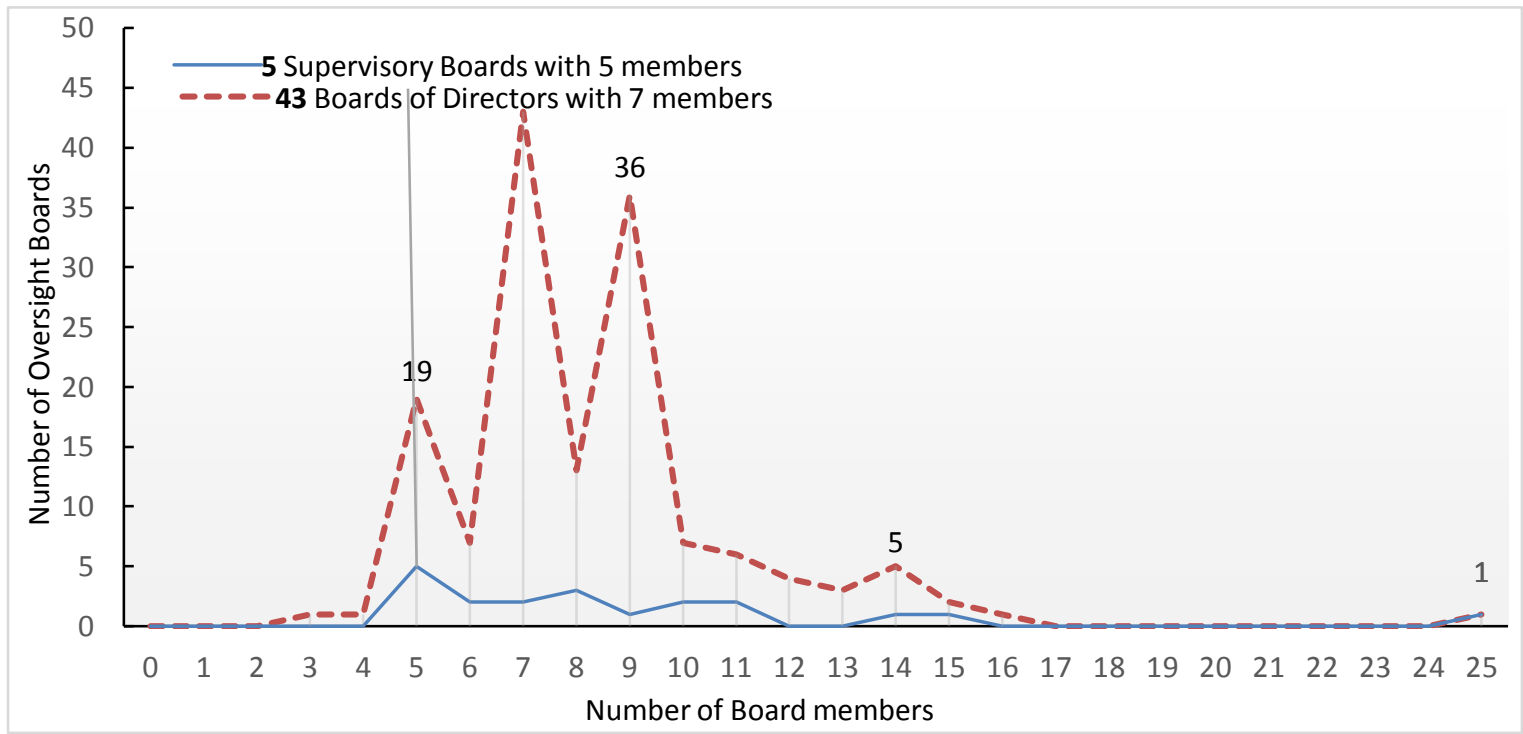

\section{Is the best approach some degree of flexibility?}

Many of the arguments in favor of a Board larger or smaller than the 8 to 9 members anchor can be balanced by having a provision allowing for a varying size of Board membership. Arguably, a statutory requirement between a minimum and maximum number of non-executive Board members provides for some calculated flexibility, while at all times safeguarding the non-executive majority.

However, when Boards of Directors are charged, in addition to oversight, with public policy formulation and/or regulatory decision-making, a more balanced representation of executives and non-executives is needed to sufficiently guarantee consideration of the "inside view" of the central bank in the decisionmaking process. In such instances, we would recommend having a fixed number of non-executive Board members. 


\section{Chair of the Oversight Board}

"the extent to which a system of this kind is really a system of rule by man and not by law (...) is extraordinarily dependent on the personalities involved" (Milton Friedman, 1962 ${ }^{78}$ ).

81. Issue-The person who chairs the Oversight Board can have a significant influence over how that Board functions. This is explained by a variety of factors, including technical ones, such as the ability of the chair to set the agenda during Board meetings or the casting vote that the chair has in case of a tie. ${ }^{79}$ The influence that the chair yields on the Oversight Board is also explained by human factors, such as the sheer reputation of the chair as one of the most respected, visible and powerful civil servants in the country, monetary union or the world, ${ }^{80}$ or the fact that an executive chair may be the hierarchical superior to other executive Board members (Deputy-Governors), thus reducing the latter's incentive to dissent from the chair's views if they have the impression that it could be prejudicial to their careers. ${ }^{81}$

82. If, as discussed above, the Oversight Board must be sufficiently autonomous from executive management, the question arises as to the impact of an executive chair on the autonomy of the Oversight Board. Again, this is not a problem with Supervisory Boards: as these are inherently composed of non-executive members only, their chair will also be non-executive. This is quite different with Board of Directors. Historically, central bank Boards of Directors were chaired by the Governor, i.e. the chief executive officer of the central bank. This was certainly a reflection of a broader trend in many corporate traditions where the Board of Directors was chaired by the chief executive.

83. Having the Governor chair the Board of Directors is, up to a degree, logical when the Board also formulates monetary policy. (The logic of this paragraph also applies mutatis mutandis to other sovereign economic policies entrusted to the central bank.) The Governor is the "face" of monetary policy and having him/her chair the body responsible for monetary policy formulation allows the central bank to present a unified and clear guidance on its monetary policy stance to the markets. It is often the case that senior central bank officials signal different

\footnotetext{
${ }^{78}$ See Friedman's chapter VIII Should there be an independent Monetary Authority, p.235 in Yeager's In Search of a Monetary Constitution, 1962. Friedman also made a comparable statement in Capitalism and Freedom, 1962, p.50 where he writes "Mistakes, excusable or not, cannot be avoided in a system which disperses responsibility yet gives a few men great power, and which thereby makes important policy actions highly dependent on accidents of personality" as well as in Friedman and Schwartz, A., A Monetary History of the United States, 1963.

79 Indeed, it was noted that the chair "sets the agenda and frames the options on the table" allowing him to "guide (...) the discussion [of his Board] toward directions he believes useful and away from those he disfavors." See Irwin, N., The Alchemists p.266, 2014.

${ }^{80}$ As a proxy of the importance that two central bank governors who also chair their Oversight Boards have, both Forbes and CEO World magazines have ranked Mario Draghi and Jerome Powell in the top 20 most powerful individuals in the world in 2018 next to heads of states and major Chief Executive Officers of influential companies such as Google or Amazon.

81 The influence of the central bank's Board's chair on their institution was analyzed extensively in the literature. For a good summary, see Siklos, P., The Changing Face of Central Banking, p. 83.
} 
opinions with regard to the state of the economy, e.g. in interviews by market analysts. Having the Governor chair the monetary policy body is beneficial to markets given that, in case of inconsistent views, central bank watchers can refer to the opinion of one very visible public servant: the Governor, which provides confidence as to the monetary policy stance that the central bank will likely adopt in the future. More fundamentally, the inside view of the central bank, which is represented by the Governor, must have an important say in monetary policy formulation, as the central bank staff is likely the most well informed as to the latest state of monetary affairs in the country.

84. But could this at the same time lead to too dominant an executive influence over the Board of Directors and be an obstacle to effective oversight?

85. In the corporate world, one can observe a significant debate on the issue of executive versus non-executive chairs. Some jurisdictions have made progress toward non-executive chairs, while others maintain largely the tradition of executive chairs. An interesting role is being played in this regard by Corporate Governance Codes for listed companies. For instance, in the King Report on Governance for South Africa 2009 (King III Report), Principle 2.16 reads as follows: "The board should elect a chairman of the board who is an independent non-executive director. The CEO of the company should not also fulfill the role of chairman of the board." The UK Corporate Governance Code of 2018 prescribes that "The roles of chair and chief executive should not be exercised by the same individual" (Provision 9). This principle is however not followed by all leading countries, as it is not enshrined in general company law, nor in the Corporate Governance Code, or because the country has not adopted such a Code. ${ }^{82}$ This said, one can observe a slow but quite certain push toward non-executive chairs. As the OECD summarizes it: "Nearly two-thirds of the jurisdictions with a one-tier board system require or encourage the separation of the board chair and the CEO." ${ }^{83}$ For the governance of commercial banks in particular, the World Bank, in its 2011 Bank Regulation and Supervision Survey, ${ }^{84}$ shared some interesting information summarized in (Figure 12).

\footnotetext{
${ }^{82}$ For more details, see OECD Corporate Governance Factbook 2017.

${ }^{83} \mathrm{Ibid}, \mathrm{p} .97$.

${ }^{84}$ For more details, see either the 2001, 2003, 2004, 2007 or 2011 World Bank's Bank Regulation and Supervision Survey.
} 
Figure 12. Requirement for Separation of Chair and Executive in Commercial Banks' Boards

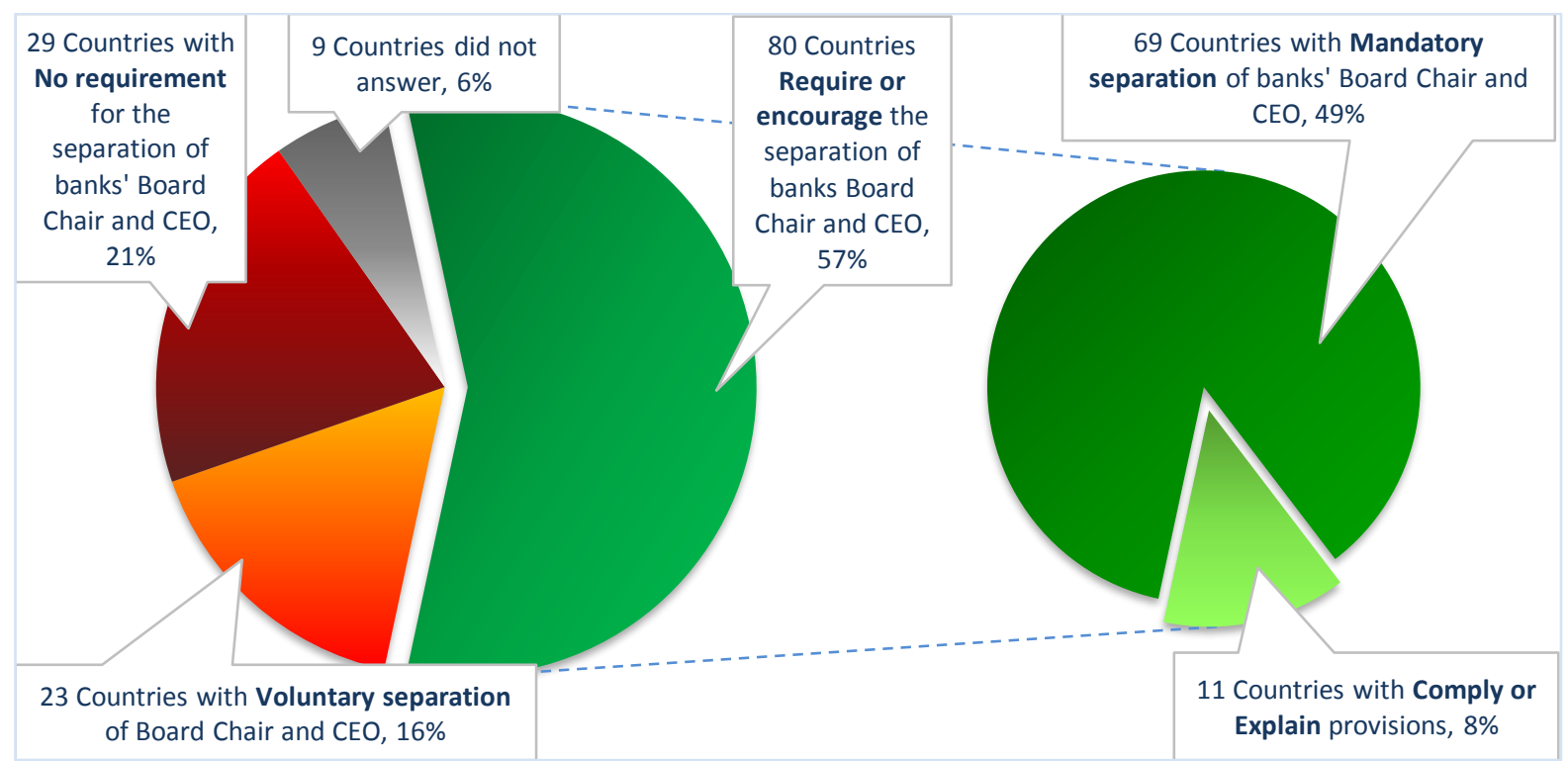

Source: IMF staff.

86. Country Practice - With regard to central banks, the practice among Fund members as summarized in (Figure 13) below shows a somewhat surprising image. Overall, of those central banks with a Board of Directors, a large majority (88\%) still have an executive chair, while a substantial group (12\%) has a non-executive chair. Moreover, the statistics show unsurprisingly that Boards without monetary policy formulation responsibilities have a higher percentage (15\%) of non-executive chairs than Boards with monetary policy formulation responsibilities (13\%). The surprising part, however, is that indeed $13 \%$ of Boards with monetary policy formulation responsibilities have a non-executive chair.

Figure 13. Executive vs. Non-Executive Chairs in Boards of Directors

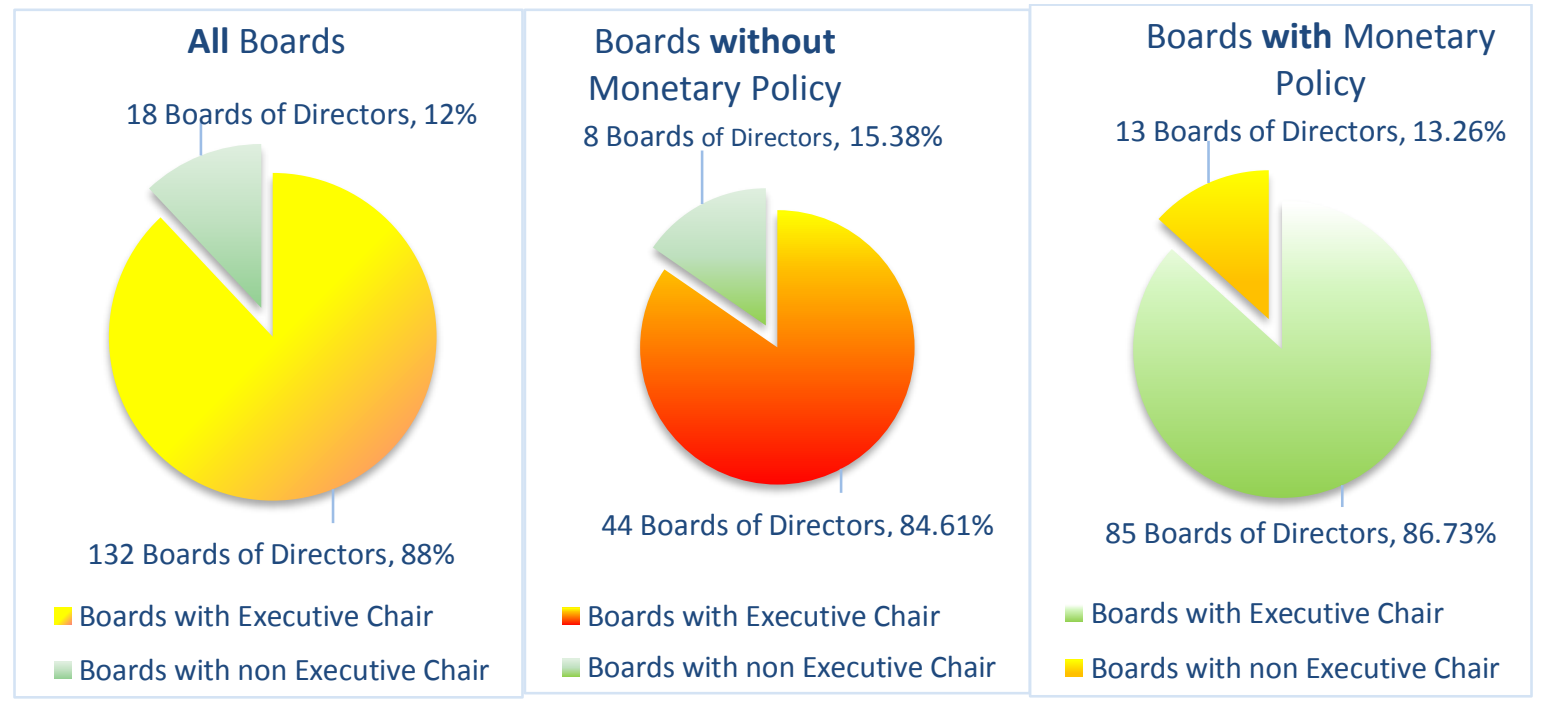

Source: IMF staff. 
87. Staff's Advisory Practice - Fund staff has followed a nuanced approach vis-à-vis this issue.

- Where countries have switched to a non-executive chair for a Board of Directors that is not entrusted with monetary policy formulation, staff has cautiously supported this move. Specifically, staff has acknowledged that appointing a non-executive chair to such Oversight Boards has advantages from the overall perspective of oversight quality by strengthening independence from executive management. But such a set-up can also give rise to some risks and complications. In particular, a situation must be avoided where a nominally non-executive chair becomes too involved in executive management, and thus competes with the Governor as head of executive management and indeed the institution. Also, the legal framework will need to clarify who represents the central bank in which cases. ${ }^{85}$

- $\quad$ For central banks whose Boards of Directors are entrusted with monetary policy formulation, staff has warned that a robust substantive and procedural role for the central bank's executive management in public policy formulation is critical. (A similar logic could apply when the Board of Directors in entrusted with other public policies, e.g. on financial stability and payment systems oversight.) In such cases, it is understandable that the Board has an executive chair, in the person of the Governor. However, staff has also suggested remedies to mitigate the risk of excessive executive dominance over the Board, for instance the requirement that the Board meet at least once per year under a non-executive chair to discuss performance of executive management.

\section{Presence of Public Sector Oversight Board Members}

"We can worry about inflation after we get re-elected." (R. Nixon, 1972)

88. Issue-Since the two World Wars, which turned central banks into full-fledged instruments of State policy, it was common to have Public Sector officials ${ }^{86}$

\footnotetext{
${ }^{85}$ For instance, the Governor should represent the central bank when rendering accounts on monetary policy decisions, while the non-executive chair of the Board should represent the central bank when rendering accounts on the Board's oversight activities.

${ }^{86}$ In this section, we understand "Public Sector officials" as any politician, from either the central or local Legislative or Executive branch of the government, or civil servant working outside of the central bank.
} 
involved in central bank decision-making. ${ }^{87,88}$

- Many central banks had (and a few of them still have) senior civil servants as members on their Oversight Board, which was often charged with public policy formulation too. Generally, this was the highest-ranking civil servant in the Ministry of Finance (the Secretary-General or Permanent Secretary) or the Treasury (the Director-General). ${ }^{89}$

- $\quad$ As an alternative, some central bank laws allowed (and some of them still allow) the Minister of Finance (or his representative) to attend Board meetings, sometimes with, sometimes without, a vote.

89. Having Public Sector officials on Oversight Boards is theoretically defendable: monitoring by large shareholders sophisticated enough to process financial information and evaluate executive management is one of the main internal mechanisms for the governance of corporate entities. ${ }^{90}$ These major shareholders will exercise their influence for example during the appointment of Board members at the general assembly of shareholders. As central banks' capital has progressively been taken over by the State (which is responsible for recapitalizing the central bank, when and if needed) and almost no modern central bank has a general assembly of shareholders, there is an argument for the State to exercise oversight over executive management at the highest level of the internal governance structure of the central bank, through the presence of Public Sector Board Members. ${ }^{91}$

\footnotetext{
${ }^{87}$ Even prior to the World Wars, when central banks were often owned by private shareholders, Public Sector officials were sometimes present in the decision-making structures of the central bank, but their main task was to ascertain that the interests of private shareholders and the State were aligned. Their main tools were often "negative," e.g. in the form of veto powers. Such was, for instance, the case of Mexico where, in 1925 it was legislated that a minority of the central bank's capital was to be held by private shareholders (which in practice was mostly subscribed by commercial banks) and the Minister of Finance and Public Credit was empowered to veto decisions of the Board of Directors. See Exposición de Motivos de la iniciativa de decreto por el que se reforman los artículos 28, 73 y 123 de la Constitución Política de los Estados Unidos Mexicanos, enviada al H. Congreso de la Unión por el Ejecutivo Federal, p. 1.

${ }^{88}$ We distinguish this involvement from the prerogative of government or the Minister of Finance to appoint "commissioners" with suspension and/or veto rights over decisions taken by the central bank's decision-making bodies. Sometimes, such a veto right only applies when the commissioners deem a central bank decision illegal, sometimes commissioners also can veto decisions on policy grounds.

${ }^{89}$ In 1961, for a sample of 21 central banks, 17 had at least one ex-officio member from the government sitting on their Oversight Board. Often, it was the Minister of Finance in person or his deputy. See Aufricht, H. Central Banking Legislation, IMF, 1961, p. 982.

${ }^{90}$ Frisell, L., Roszbach, K. and Spagnolo, G., Governing the Governors: A Clinical Study of Central Banks, Sveriges Riksbank, WP 221, 2008, p3. See also Davie, L., and Paul, G., The Board of Directors: Composition, Structure, Duties and Powers, OECD, 2000, p. 3.

${ }^{91}$ The other argument that is often presented to defend the presence of Public Sector officials in the Boards of central banks is the need to coordinate monetary and fiscal policy, which is not an oversight issue. While we acknowledge the need for such coordination, we believe there are better mechanisms through which such a coordination can be provided. For instance, a formal coordination mechanism in the form of a committee can be established between the central bank and the Ministry of Finance.
} 
90. However, such presence raises fundamental concerns about both the personal and institutional autonomy of central banks (see para. 17). Specifically, the presence of the Minister of Finance and senior civil servants-irrespective of whether they have voting rights or not-can lead to a "chilling effect" on central bank decision-making: the decision-making bodies of the central bank could internalize political expectations or constraints, even if this is not the best way to achieve the central bank's objectives. The fact that Public Sector Board members are only one or a few of a larger "college" does not modify this conclusion, because the Minister of Finance or his/her representative(s) speak with the full might of the political powers behind their opinion. Their role will be even more influential when the Public Sector Oversight Board members have a say in the dismissal or re-appointment of the other Board members. ${ }^{92}$

91. While at first sight this risk may be most salient in respect of public policy formulation (e.g., to lower policy interest rates with a view to stimulate the economy before an election or to lower the cost of debt service) ${ }_{1}^{93}$ it also occurs in the context of oversight (e.g. with respect to profit retention and dividend allocation decisions).

92. Country Practice -A large majority of central banks have no or only a small minority of voting members from the Public Sector serving on their Oversight Boards. ${ }^{94}$ As can been see in the (Figure 14) below, 98 Oversight Boards (58\% of them) have no Public Sector officials vested with voting rights serving on them. 20 Oversight Boards (11.5\% of them) have Public Sector officials on Boards in the 10 to $15 \%$ band. 41 Oversight Boards (23.6 \% of them) have a concentration of Public Sector Board Members of $20 \%$ and more.

\footnotetext{
92 This aspect of the personal autonomy will be discussed in the forthcoming Working Paper announced in footnote 9

${ }_{93}$ An example of the "time-inconsistency dilemma" stemming from political interference was given by John Taylor: "Faced with the forthcoming re-election, President Nixon asked Friedman to convince the President of the Federal Reserve System, Arthur Burns, to increase the money supply in order to stimulate the economy. When Friedman protested that this would only lead to higher inflation in the future, Nixon replied: "we can worry about inflation after we get re-elected". See the speech given by González-Páramo, J., Expectations and credibility in modern central banking: A practitioner's view, 2007.

94 The opposite is true for the 4 central banks that do not have Oversight Boards, as in their case the oversight over executive management will be directly assumed by a governmental body set outside the central bank that by definition is largely if not exclusively populated by Public Sector officials.
} 


\section{Figure 14. Percentage of Public Sector Oversight Board Members (with voting power)}

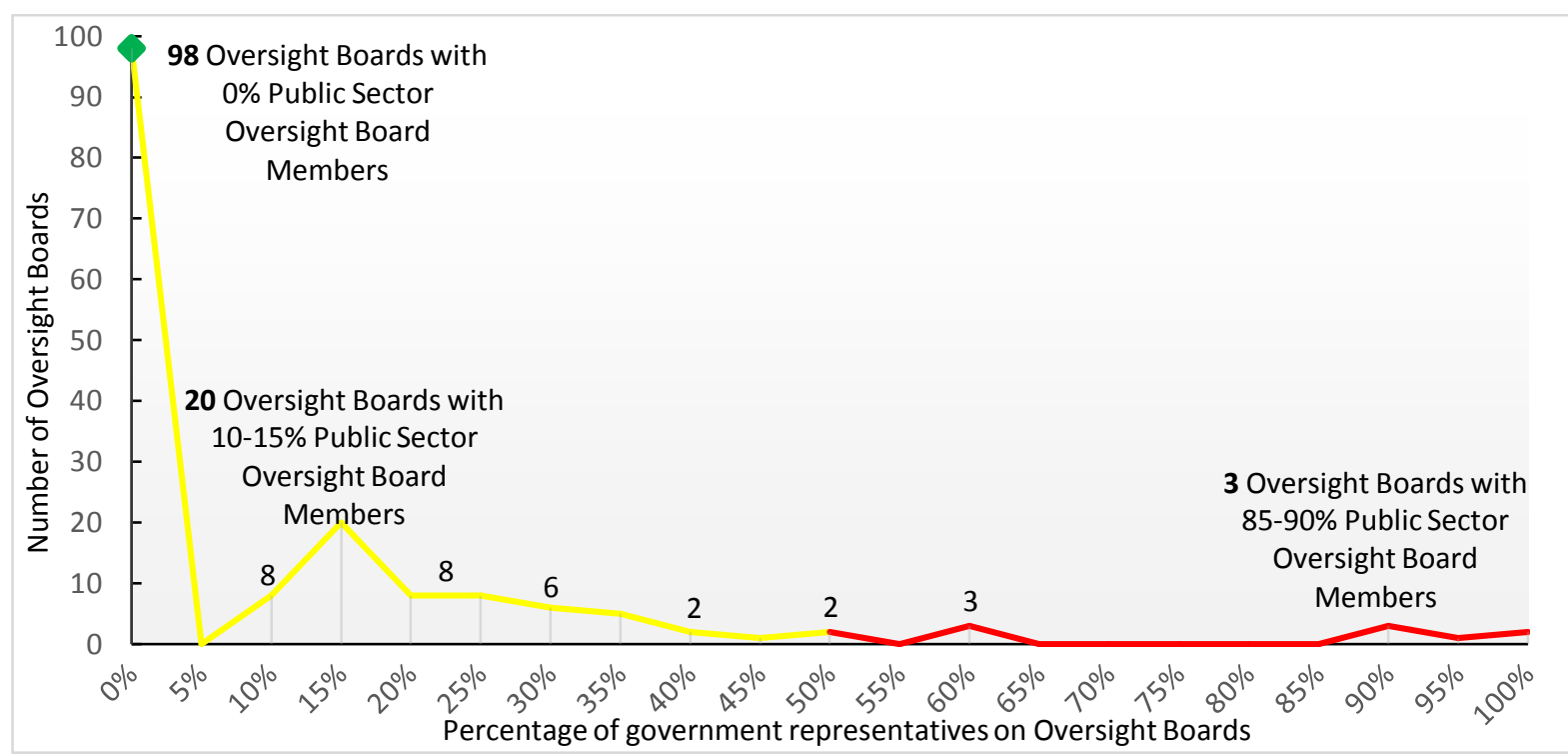

Source: IMF staff.

93. Staff's Advisory Practice-Fund staff's views with respect to the presence of Public Sector officials in decision-making bodies of central banks depends on the portfolio of decisionmaking responsibilities that are allocated to the decision-making body in question. With regards to Oversight Boards specifically, Fund staff's advisory practice can be summarized as follows:

- Boards of Directors charged with Monetary Policy Formulation-Because the risk of political abuse is most acute in this case, Fund staff has been strongly opposed to the presence of politicians and civil servants in the decision-making body charged with monetary policy formulation. ${ }^{95}$ Obviously, this opposition is stronger to a presence with voting rights than to a presence with voice but without voting rights.

- $\quad$ Boards of Directors charged with policies other than Monetary Policy-Even if monetary policy formulation is allocated to a body distinct from the Board of Directors (e.g., a Monetary Policy Committee), many of those Boards are still entrusted with the formulation of other public policies (in particular financial stability, payment systems and statistical policies) and regulatory decision-making (in particular in the fields of payment systems oversight). Fund staff has generally advised against membership of Public Sector officials in such types of Boards. For those central banks that are also banking supervisory authority, this position is also supported by international standards. ${ }^{96}$

\footnotetext{
${ }^{95}$ Lybek, T., and Morris, J., o.c., p. 28. The advisory practices in this regard of Fund staff have not changed since 2004.

96 Principle 2 of the Basel Core Principles for Effective Banking Supervision prescribes that "the supervisor possesses operational independence." Essential Criterion 1 clarifies that "there is no government (...) interference that compromises the operational independence of the supervisor." However, Financial Sector Assessment
} 
- $\quad$ Pure Oversight Boards - Fund staff has discussed the importance of having a highly skilled and as autonomous as possible set of members of pure Oversight Boards, i.e. Boards which are only charged with oversight (i.e. Supervisory Boards or Boards of Directors charged with oversight only: see (Figure 9) and para. 58). This being said, it is also accepted that a minor presence of Public Sector officials here is less damaging to the overall autonomy of central banks, even if some forms of abuse cannot be excluded (e.g. with regards to profit reservation versus distribution decisions).

94. As a legal matter, prohibiting the appointment of Public Sector officials as members of the decision-making bodies of the central bank is achieved through the so-called incompatibility criteria. These are criteria that prohibit persons to be appointed to, or remain in function in, a decision-making body of the central bank. These criteria need to be established in the central bank law. Currently, most central bank laws prohibit members of the Legislature and of the Executive branch of government as well as civil servants to serve on the Oversight Board. However, a significant number of central bank laws do not prohibit, or only partially prohibit, ${ }^{97}$ members of political bodies and the public administration to sit on their central banks' Oversight Boards.

95. Typically, Fund staff will recommend adopting legislative provisions that prohibit politicians (i.e. both members of the Executive and the Legislative) as well as civil servants to be appointed to decision-making bodies of the central bank. The only common exception to this principle is the acceptability of academics in public university institutions.

96. If a "first best" is not achievable, transitory measures that allow to diminish the influence of Public Sector officials over central bank Boards consist of (1) only allowing such officials to attend Board meetings without the right to take part in the debates and/or (2) making their presence only an advisory and not a voting one.

97. Last but not least, Fund staff has displayed a significant degree of flexibility in this regard for very small or low capacity countries. In many of those countries, the talent pool for nonexecutive officials is very small, certainly taking into account the eligibility and incompatibility criteria. For instance, most of the persons meeting the eligibility criteria may sit on the board of supervised financial institutions, and hence be conflicted. In other countries, most persons who meet the eligibility criteria work for the State either directly or indirectly (e.g., for State-Owned Enterprises).

\footnotetext{
Programs identified that, in several jurisdictions where the supervisory authorities are hosted in central banks, a number of factors could still compromise their operational independence. See IMF, Global Financial Stability Report, A Decade after the Global Financial Crisis: Are We Safer? October 2018, p. 69.

${ }^{97}$ The most reoccurring example of such incomplete provisions consist in the central bank laws that only prohibit members of the Legislative branch of the government to serve on their Oversight Boards and not of the Executive as well.
} 
- $\quad$ Under such circumstances, Fund staff has not objected to a certain number of civil servants sitting on the Oversight Board of the central bank. While the risk of politically directed decision-making cannot be avoided, Fund staff has tried to mitigate some risks by advocating "in their capacity" (qualitate qua) appointments, where for instance the directors-general of the public debt management and economic planning units in respectively the Ministries of Finance and Economy are appointed to the central bank's Oversight Board, in their official capacity.

- $\quad$ Other Fund staff advice to such jurisdictions was to remove nationality requirements from the eligibility criteria so as to allow for the appointment of foreign nationals as Board members and for their attendance to Board meetings not to entail costly travel arrangements, by allowing the Board meetings to take place via teleconference or other such arrangements.

\section{Strong Eligibility Criteria}

"(...) We have placed the exclusive custody of our entire banking reserve in the hands of a single board of directors not particularly trained for the duty—who might be called 'amateurs'" (Walter Bagehot, Lombard Street A Description of the Money Market, 1873, p. 42)

98. Issue-Eligibility criteria are the positive legal criteria that must be met for a central bank official (Governor, Deputy Governors, Oversight Board member, etc.) to be eligible for appointment by the appointing authority(ies). As will be discussed below, many but not all central bank laws include such type of criteria. If they are included in the central bank law, they are supposed to bind the appointing authority(ies) in the legal act of appointing the relevant official(s). Eligibility criteria must be distinguished from the above-mentioned incompatibility criteria, which are the negative legal criteria that must not be met for the said appointment.

99. The role of strong eligibility criteria for the executives of central banks (Governor, Deputy-Governors) is well recognized. ${ }^{98}$ If, however, there is a big gap between the competency levels of executives and non-executives, this can cause major governance challenges, and in particular dominance of executives over non-executives. Even with a non-executive majority on the Board-in and of itself a good practice-this may give rise to too weak an oversight over executive management because of a lack of expertise. In such a situation, the whole Board may be captured by the few executives serving on it.

100. Increasingly, attention is being paid by Legislatures to the eligibility criteria for nonexecutive Oversight Board members. In the past, central bank laws would establish eligibility

\footnotetext{
${ }^{98}$ See for example, Athanassiou, P., Reflections on the Modalities for the Appointment of National Central Bank Governors, in European Law Review, 39(1) (2014), p. 27-46.
} 
criteria in function of the professional origin or affiliation of Board members. ${ }^{99}$ The rationale behind this approach was to ensure that the central bank Board would take decisions that are buttressed by (a) a sound knowledge of the various components of the national economy (agriculture, commerce and industry) or (b) institutional stakeholders in the socio-economic process (employers' federation, trade unions). Today, this focus is increasingly being redirected toward the skills necessary to exercise effective oversight. More and more central bank laws will set out some minimum levels of education, experience and/or technical skills required from nonexecutive Board members. In part, this has been combined with the allocation of monetary policy formulating responsibilities to a specialized committee with highly defined eligibility criteria for its members.

101. Country Practice-As is summarized in (Figure 13) below, a large majority (81\%) of central banks have insufficient eligibility criteria for non-executive Oversight Board members: their central bank laws contain either no, or irrelevant $(26 \%),{ }^{100}$ or weak eligibility criteria (55\%). ${ }^{101}$ Only $14 \%$ of central banks have either moderate $(10 \%)^{102}$ or strong $(4 \%)^{103}$ eligibility criteria in their organic legislation.

\footnotetext{
99 The examples of the USA, Belgium and South Africa illustrate this point. In the Federal Reserve System, the Boards of Directors of the constituent Reserve Banks are composed of nine directors, of which six will be elected or appointed "with due but not exclusive consideration to the interests of agriculture, commerce, industry, services, labor, and consumers" (Section 4.11-12 of the Federal Reserve Act). In the National Bank of Belgium, of the ten non-executive directors ("Regents), "Two Regents shall be chosen on the proposal of the most representative labour organisations. Three Regents shall be chosen on the proposal of the most representative organisations from industry and commerce, from agriculture and from small firms and traders." (Art. 23 NBB Law) In the South African Reserve Bank, seven of the fifteen directors are elected by shareholders, with the Act requiring that two shall be persons who are or have been actively and primarily engaged in commerce or finance; one shall be a person who is or has been so engaged in agriculture; and two shall be persons who are or have been so engaged in industrial pursuits (Art. 4 (9) of the SARB Act 1989).

${ }^{100}$ An eligibility criterion is considered to be inexistent or irrelevant where central bank laws did not mention either professional experience or education.

${ }^{101}$ We considered an eligibility criterion to be weak when the central bank law focuses on education or some professional experience, but not on the two combined.

102 We considered an eligibility criterion to be moderate when the central bank law has a combined focus on education and some minimum professional experience.

103 Strong eligibility criteria in the central bank law had to encompass education and robust minimum professional experience, including in senior positions, as well as rules to ensure diverse skillset in Oversight Boards.
} 


\section{Figure 15. Eligibility Criteria for Non-Executive Oversight Board Members in Central Bank} Laws

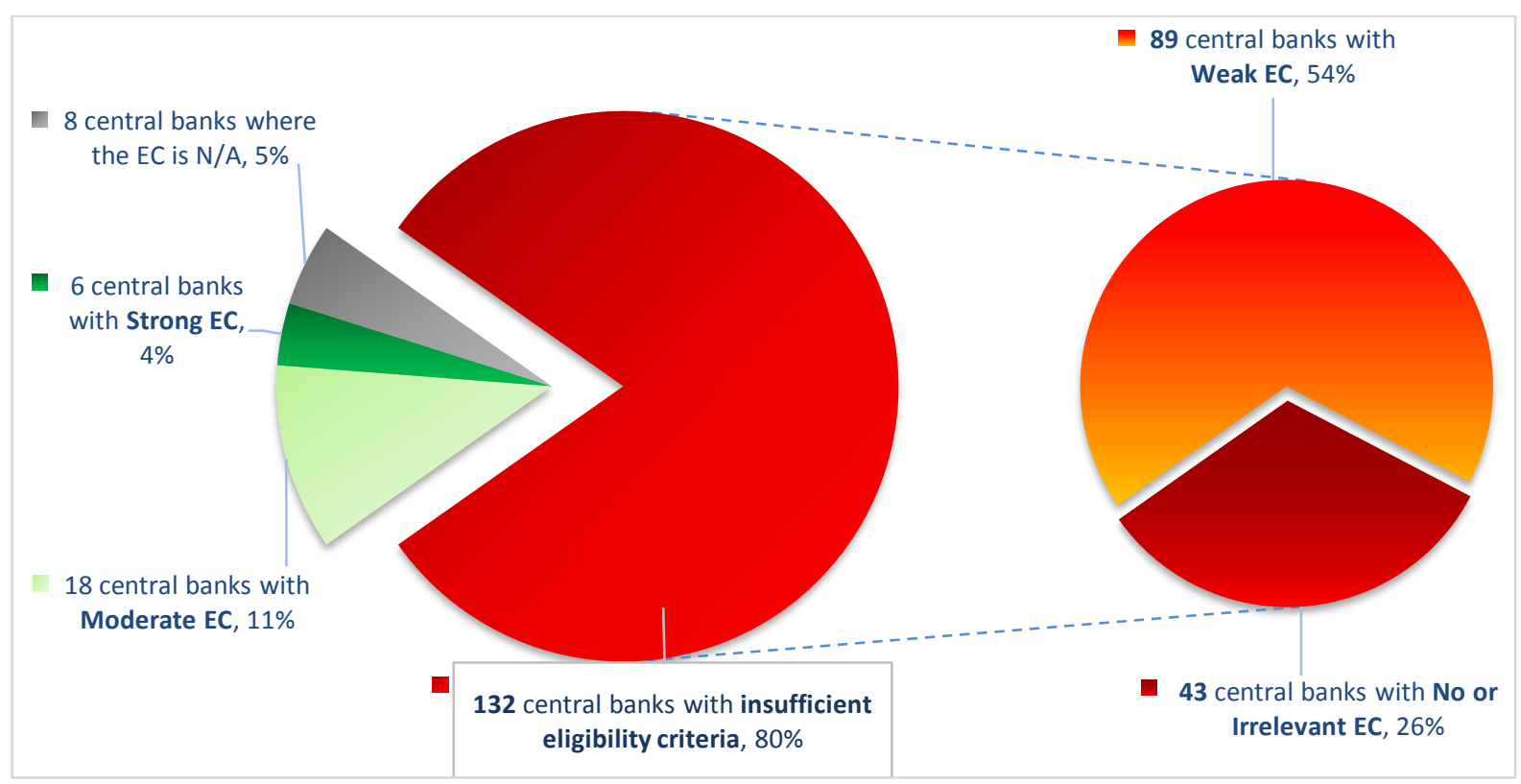

Source: IMF staff.

102. Among the large subset of central banks with weak eligibility criteria, one common problem is that the requirement for professional experience is too loosely drafted in the central bank law, either with regard to (1) the depth of experience that a candidate should have (e.g. that they should be "professionally capable" or having a "shown capacity" or "well-known capacity") and/or (2) the field of competencies in which potential Board members should have expertise (e.g. "experience in business, professional or academic matters" or "selected from various occupations"). Rarer, but equally unsatisfactory, is the situation where the central bank law sets a minimum education criterion such as a university degree but no professional experience. Certain central bank laws contain requirements that do not help to make an objective enough call on the best candidates for non-executive Board positions, such as persons with "good manners" or with "patriotism". Also, many central bank laws have a more precise but still insufficient wording such as persons with "significant", "ample" or "wide" experience or who are an "eminent professional".

103. Staff's Advisory Practice - In line with general governance principles and practices from banking supervision, we can posit the general rule that non-executive Oversight Board members should individually and collectively be "fit" to perform their duties. But what is the right skillset for non-executive Oversight Board members of central banks? The answer to that question depends on the decision-making responsibilities allocated by the central bank law to the Oversight Board.

- $\quad$ Pure Oversight Boards-For Boards with only oversight responsibilities, a broad skillset covering financial reporting, audit, finance, risk, legal, compliance and increasingly also engineering (to deal with IT and cybersecurity issues) would best contribute to robust oversight. 
- $\quad$ Boards with Other Responsibilities-For Board of Directors that have, in addition to oversight, also public policy formulation and regulatory decision-making responsibilities, the skillset will need to be even broader and also include directors with a background in macro-economics, monetary economics, banking and finance.

104. The fundamental legal question is whether central bank laws can, and if so, should, legislate a diversity of skills within the Oversight Board? This is a difficult question. While we believe it is legally possible to legislate a diverse skillset in the Board, we have not seen many examples of central bank laws that endeavor to achieve this outcome. One example is the Central Bank of Ireland, which has one such provision in its law: "the person has relevant knowledge of(a) accountancy, (b) actuarial science, (c) banking, (d) consumer interests, (e) corporate governance, (f) economics, (g) financial control, (h) financial regulation, (i) financial services, (j) insurance, (k) law, (l) social policy, or (m) systems control" (Section 24 (1)). Another example is the Central Bank Law of Mauritania, which includes a provision requiring that "the overall composition of each Board ensures a balance of the various technical skills required" (Art. 28, $\left.2^{\text {nd }}\right)$. An intermediate solution is to require the appointment of at least members with certain necessary skills, with a high experience requirement. This is what is done in Serbia, where the law requires "at least one member of the Council (...) with 10 years of work experience in accounting or auditing" (Art. 22 in fine).

105. In the absence of clear good practice in regard of the above, Fund staff focuses on ensuring an overall minimum level of professional skills among non-executive Board members. This is typically achieved by requiring in the central bank law:

- $\quad$ An advanced university degree in economics, finance, law, audit, engineering, IT;

- A minimum number of years of professional experience; and

- A minimum number of years of experience in senior position.

106. Introducing such requirements in a central bank law can contribute to enhancing the professional quality of non-executive Board members, but such an approach in and of itself will not necessarily produce miracles. Other, non-legal initiatives may be equally important to enhance the quality of non-executive Board members, such as effective "on boarding" processes and training.

107. Finally, one cannot lose sight of the fact that the appointment of central bank officials is inherently a political appointment, which involves a political judgment. Once a certain minimum level of quality is met, other factors can come in to play: gender, ethnic, geographic or religious diversity, etc. This being said, central banks are becoming increasingly complex institutions (think about cyber risk and Fintech), ${ }^{104}$ which puts an ever-higher requirement of skills on their key

\footnotetext{
104 There are now two central banks that have a Chief Fintech Officer: see Central Bank Directory, Ed. 2019. To exercise effective oversight over Fintech endeavors of central banks, it is important that Oversight Boards also have members with established Fintech expertise.
} 
officials. The best contribution to robust skill-sets in central bank Oversight Boards, and of course the other decision-making bodies too, is the firm and deeply rooted conviction among political decision-makers that professional skills should be the most important factor in determining suitability for appointment. ${ }^{105}$ Adequate political accountability mechanisms (e.g., before the Legislature) for the appointing authority could contribute to establishing such a conviction.

\section{Oversight Procedures}

108. Issue-Most central bank laws include one or more procedural aspects related to the operation of the Oversight Board. Fund staff has not observed major hiatus in this regard. The issue is, however, one of carefully reviewing what is established and giving due consideration to procedural rules that may be fine-tuned or enhanced.

109. Staff's Advisory Practice - Fund staff advocates that central banks laws and other legal instruments (By-Laws, internal decisions of the Oversight Board) should cover the following procedural aspects:

- Minimum number per annum and periodicity of Oversight Board meetings: this number should be sufficient to ensure effective oversight, yet not be too high so as to incite the Board to be engaged in executive decision-making. ${ }^{106}$ For most central banks, 5 to 10 ordinary meetings per year, with respectively bimonthly or monthly meetings, seems sufficient, taking account that the Audit Committee and other sub-committees of the Oversight Board (e.g., Remuneration Committee) will have additional meetings in between regular Oversight Board meetings. This number will vary depending on the decision-making responsibilities entrusted to the Oversight Board: a Board vested with policy formulating responsibilities may need to convene more often than one that does not have such powers.

- Quorum, including minimum presence of non-executives: an adequate quorum should ensure that a sufficient number of members of the Oversight Board is present during deliberations. For a Board of Directors, the quorum should require the presence of a minimum number of non-executive directors that is larger than the total number of

\footnotetext{
${ }^{105}$ A very interesting example of an attempt to balance political with capacity requirements is the Memorandum of Understanding between the Swiss Federal Department of Finance and the Swiss National Bank on the "Set of Principles governing membership of the Swiss National Bank's Bank Council": The MoU includes both an undertaking between the parties to regularly discuss requirements for prospective Council members as well as substantive principles governing membership of the Bank Council. In addition to requiring technical capabilities, the latter Principles also seek "adequate representation of the different parts of the country and language regions" and include an aim "to achieve appropriate representation of both genders in the Bank Council" (Principle 7).

$106 \mathrm{It}$ is interesting that central bank laws sometimes require a minimum number of Oversight Board meetings per year, but rarely mention a maximum number of meetings. This is reasonable, as directors can always call for extra-ordinary board meetings. However, at least in theory this allows for the possibility that the Oversight Board meets too often to be a proper Oversight Body and becomes another executive body of the central bank.
} 
executive members, lest the Board operate with an executive majority. To be able to operate effectively, this brings into relief the importance of a sufficient size of the nonexecutive majority of Board members serving on the entire Board.

\section{Box 3. Quorum and Size of Non-Executive Majority on Boards of Directors}

If decisions of a Board of Directors require a quorum that is substantially inferior to its full membership, four factors may cause decisions to be effectively taken by an executive majority, even if the central bank law foresees a majority of non-executive members of the whole Board.

First, the non-executive majority calibrated in central bank laws is, in many cases, very narrow. 29 Boards of Directors have a non-executive majority of one to two non-executives.

Figure: Size of the Non-Executive Majority

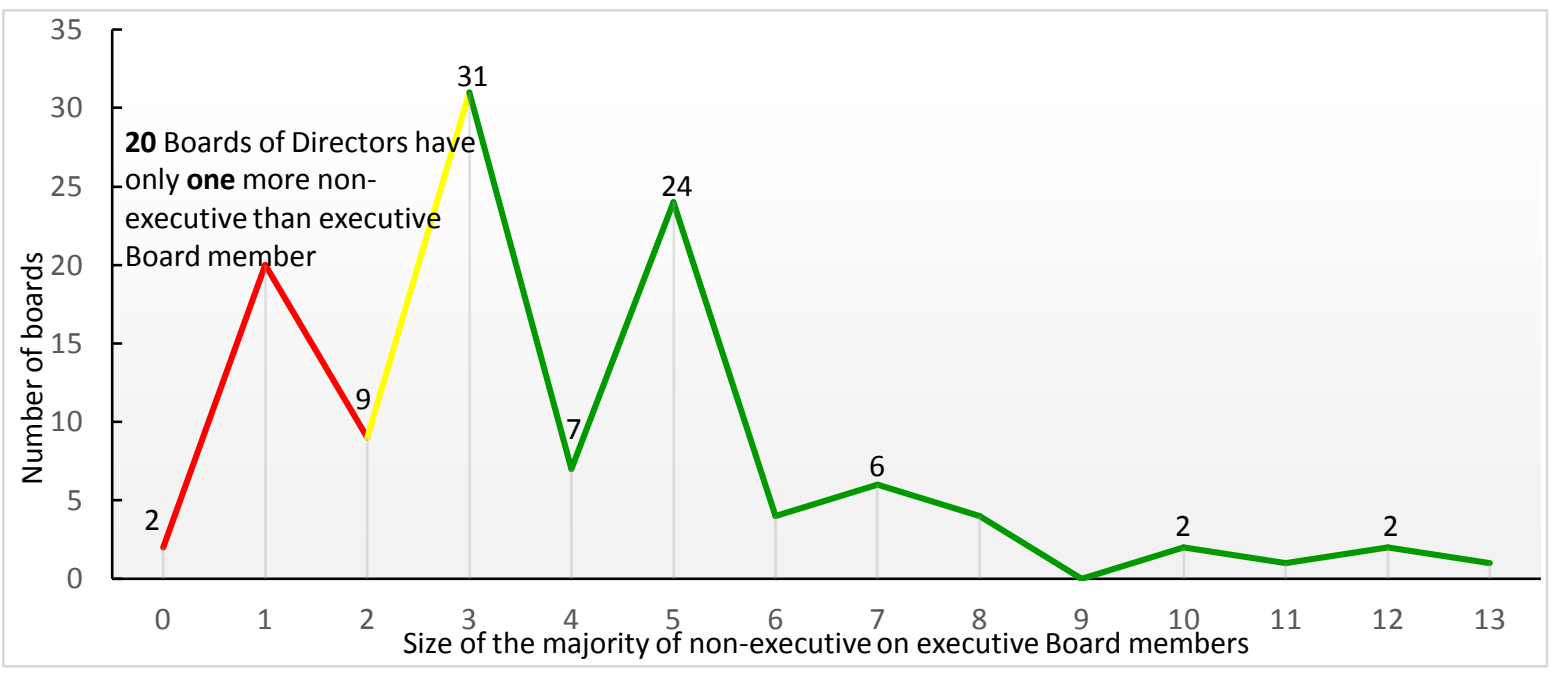

Second, in many Boards, non-executive Directors' positions tend to be vacant more often and for longer periods than those of executive management (see para.79). As a result, the actual ratio of executives to non-executives tends to be higher than what is foreseen in the law.

Third, a 130 of the 148 Boards of Directors are chaired by an executive with a casting vote in case of a tie. In such a case, if the number of executives attending the Board meeting equals the non-executives, the executives still have a hold on the voting power.

Fourth, under several central bank laws, the (re-)appointment of Directors depends upon the assessment of the Governor. Those Directors might tend to align their views with those of the Governor. This could be considered as an application of Keynes' "beauty contest factor" (1936).

While the last factor should be mitigated by removing any role of executives in the appointment of nonexecutives, the first three factors could be addressed by a provision in the central bank law establishing a quorum that always consists of a non-executive majority - this is a best practice. (see the example of the Malaysian central bank quoted in Box 4).

Furthermore, Boards would often benefit from increasing the number of non-executives relative to executives. We believe that a majority of minimum three non-executives for smaller Boards is a good practice, while larger Boards should strive for a minimum of a four members non-executive majority. 


\section{Box 3. Quorum and Size of Non-Executive Majority on Boards of Directors \\ (Continued)}

\section{Boards of Directors vested with Oversight Only: Model for Size and Composition}

As written in Box 2, the size of central bank Boards will vary upon a variety of factors, including the complexity and size of the economy (1). In turn, the size of the Board will determine the size of the non-executive majority, which will also be influenced by the decision-making responsibilities allocated to the Board. Another influencing factor is the central bank mandate (2) which is correlated to the complexity of the decision-making responsibilities of the Board. In combination, this allows us to propose the following size, composition and quorum for three different stylized central bank Boards of Directors (with Oversight powers only).

Small Size or Simple Economy and narrow or typical central bank mandate:

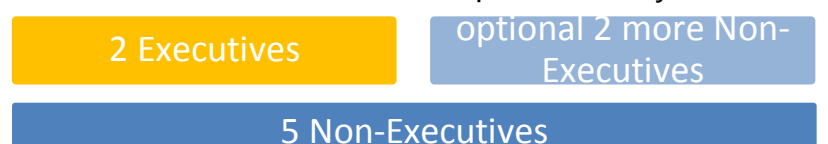

5 Non-Executives

4 Member Quorum with 3 NonExecutives

Medium Size or-not-too complex economy regardless of the mandate;

Small Size or simple economy and extensive central bank mandate; Large Size or Highly complex economy and narrow central bank mandate:

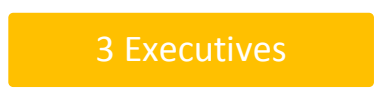

optional 3 more Non Executives

7 Non-Executives

\section{Member Quorum at least 4 Non-} Executives

Large Size or Highly complex economy and extensive or typical central bank mandate:

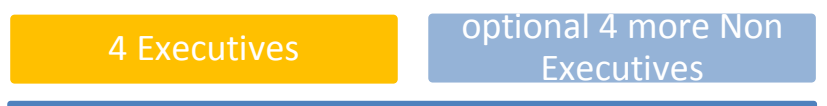

8 Non-Executives

\section{Member Quorum at least 5 Non-} Executives

\section{Implication of the Model Board size and composition for the IMF membership:}

We acknowledge that the proposed Model Board size and composition would often enlarge the size of central banks Boards of Directors by 1-3 members. We believe that such an increase is warranted as, over the last 50 years (see Aufricht), the size of central banks Boards has not expanded in function of the increase in complexity of the oversight and other responsibilities attributed to these Boards (Board size has since actually decreased by 2 members on average).

1/ For Large Size or Highly complex economies, we used as proxy the 39 advanced economies of the IMF World Economic Outlook as well as China, India, Brazil Russia, Mexico and Indonesia. For the Medium size or not-too-complex economies, we took the 34 Emerging market and developing economies that have an estimated 2019 GDP in USD Dollar of more than 80 billion but below a trillion dollars, the last 114 countries are ranked as Small Size or Simple Economies.

2/ A central bank has a typical mandate when it is vested with the objectives to (i) foster price stability, (ii) financial stability and (iii) subject to these, to support the economic policies of the government and has the functions (i) to conduct monetary policy, (ii) payments system oversight, (iii) macro-prudential policy and (iv) reserves management. A central bank that is not vested with some of these objectives and functions has a narrow mandate and a central that, in addition to such responsibilities, is vested with other objectives and functions has an extensive central bank mandate. 
- Decision-making and voting procedures, including majorities: most central bank laws lay down the principle of majority voting, with the tie-breaking vote allocated to the chair of the Board. Some central bank laws require the Board to reach a consensus when taking decisions. There are also some central bank laws that require for some types of (important) decisions a special majority (i.e. larger than absolute majority). Requiring by law $^{107}$ or practice that all decisions reach a consensus is, however, not a good practice as this may cause a dominance by a single member (often the chair) on the whole Board.

- $\quad$ Right of initiative to call for Board meeting and table agenda items: Many central bank laws will specify who has the right to call for a meeting of the Oversight Board. This is particularly important for Boards of Directors chaired by the Governor: in case only the Governor could call for a meeting of the Board or table agenda items, it is obvious that the Governor could thwart effective oversight. It is hence good practice to grant the right to call for a Board meeting to, say, two directors, and to give each director the right to table an agenda item. ${ }^{108}$

\section{Box 4. Example of Well-Drafted Legal Provisions for Oversight Procedures}

It is useful to give a few examples of how fairly succinct legislative provisions lay out some of the central procedural aspects of the functioning of a central bank's Oversight Board.

The first example is Section 19 (5) of the Bank Negara Malaysia Act, which reads as follows:

"At any meeting of the Board, the quorum shall be five directors, the majority of whom shall be (non-executive) directors (...) and decisions shall be adopted by a simple majority of the votes of the directors present and voting, provided that in the case of an equality of votes the chairman shall have a casting vote."

The second example is Article 7 of the Act on the Czech National Bank, which reads as follows:

"(1) (...) The Bank Board shall act by a simple majority of the votes cast. The Bank Board shall have a quorum if the Governor, or his nominee, and at least three other members of the Bank Board are present. In the event of a tie, the chairperson shall have the casting vote.

(2) The Bank Board shall approve the Rules of Procedure of the Bank Board."

Both legislative provisions deal with the key modalities of decision-making: simple majority of the votes cast, but conditional upon a quorum, and with a casting vote of the chair. A strength of the Malaysian example is how the quorum focuses on a non-executive majority. A strength of the Czech example is that the law explicitly empowers the Bank to adopt more detailed Rules of Procedure.

\footnotetext{
107 See Article 18 of National Bank of Rwanda statutes.

108 This is another illustration why the size of the Board matters. Non-executive members have the ability to call for Board meetings most often when at least two to three such members ask for an extraordinary meeting. The higher the number of non-executives, the easier it is for them to convene extraordinary Board meetings on matters that are important to them, i.e. presumably major findings on oversight issues over executive management.
} 
110. Given their centrality to effective Board oversight, there is a strong argument to include most if not all items mentioned in the previous paragraph in the central bank law itself. Box 4 gives two examples of well-written central bank law provisions regarding procedural aspects of the operation of the Oversight Board.

111. In addition, some other, more practical aspects of the operation of the Oversight Board can be enshrined in secondary or tertiary legal instruments (see para. 25), such as organizing Board meetings by teleconference, attendance of advisors and technical staff, and the recording of decisions of the Board. These aspects ought not to be ignored, as they provide the practical mechanisms through which oversight effectively takes shape.

\section{Oversight in Federal Central Banking Systems and Monetary Unions}

112. How do the principles set out above apply to federal central banking systems? These are central banking systems composed of (a) several national or regional central banks with separate legal personality and (b) a centralized entity. ${ }^{109}$ This point is particularly relevant as the central banks issuing the two major reserve currencies - the USA's Federal Reserve System and the European System of Central Banks (ESCB)—are such systems.

113. While some of the governance principles discussed above can easily be applied to federal central banking systems, others will need to be modified to take into account the specific federal nature of such systems. To illustrate this point, we must distinguish between those system's regional/national constituent banks, and the central entity.

114. Regional/national central banks: All the principles discussed above can be expected to apply to regional and national central banks. ${ }^{110}$ However, depending on the relationship between the central entity and the regional/national central banks, the central entity may have a say in how Oversight Boards of the latter operate, which is an idiosyncratic feature of federal systems. ${ }^{111}$ In doing so, it can introduce a second layer of oversight (from the central entity's

\footnotetext{
${ }^{109}$ Federal central banking systems are designed to reflect the political set-up of the country or the monetary union that they serve. For instance, it has been said that the design features of the Federal Reserve System were chosen to mirror the US Federal constitutional set-up as "the regional banks are the states and the Federal Reserve Board is the Congress." See the Glass House Report, 1927, as reported in Conti-Brown, P. The power and independence of the federal reserve, Princeton University Press, 2016, p.22.

${ }^{110}$ For instance, in the Federal Reserve System, "every Federal reserve bank shall be conducted under the supervision and control of a board of directors" (Section 4.6 of the Federal Reserve Act). "Much like the boards of directors of private corporations, Reserve Bank boards are responsible for overseeing their Bank's administration and governance, reviewing the Bank's budget and overall performance, overseeing the Bank's audit process, and developing broad strategic goals and directions." See The Federal Reserve System: Purpose and Function, Federal Reserve System, p. 13. In the ESCB, all national central banks have an Oversight Board as defined by this paper.

${ }^{111}$ For instance, in the Federal Reserve System, the Board of Governors - the central entity-appoints the chair of the board of directors of the Federal Reserve Banks (Section 4.20 of the Federal Reserve Act).
} 
board to the regional or national central banks' boards), which does not exist in other central banking set-ups.

115. Central entity. The legal design of the Oversight Board of the central entity depends, up to a degree, on the design of that entity, and in particular on whether the central entity is a fullfledged central bank in itself, or rather a policy coordinating entity.

- In the European System of Central Banks, the central entity is the European Central Bank (ECB) and the ECB's Governing Council can be considered as the Oversight Board of the $E C B$ for the purposes of this paper. ${ }^{112}$ Because the ECB is a full-fledged central bank, its Oversight Board plays an important role and the principles of this paper can be considered to apply, although the federal nature of the system may appear to cause some complexities. For instance, while a clear majority of the ECB's Governing Council is to be considered as non-executives vis-à-vis the ECB (the central entity) itself, they are in fact the chief executive officers (the Governors) in the member national central banks. This is however totally logical, given the federal structure of the ESCB.

- In turn, the Board of Governors of the Federal Reserve System, the governing body of the Federal Reserve System, is composed of 7 Governors, who "shall devote their entire time to the business of the Board" (section 10.1 of the Federal Reserve Act). ${ }^{113}$ The fact that all these Governors can be considered as executives of the Board for the purposes of this paper is again logical and does not raise oversight concerns, given (i) that the Board is a policy coordinating entity ${ }^{114}$ and that the operational arm of the Federal Reserve System consists of the 12 regional Reserve Banks, which each have their own Oversight Board, and (ii) that the Board of Governors "exercises the general supervision over" the 12 Reserve Banks (section 11.j of the Federal Reserve Act), vis-à-vis whom they can be considered as non-executives.

116. Similarly, for monetary unions with a unified (i.e., a single, as opposed to federal) common central bank (the case of BEAC, BCEAO and ECCB), the principles presented by the paper generally apply, but there is room to make accommodations for the specific design features of a monetary union. The legal framework of the common central bank may include

\footnotetext{
${ }^{112}$ The ECB's Governing Council has the following oversight powers (as defined by this paper): define the terms and conditions of employment of the members of the Executive Board (Art. 11.3), apply for compulsory retirement to the European Court of Justice if a member of the Executive Board no longer fulfils the conditions required for the performance of his duties or if he has been guilty of serious misconduct (Art. 11.4), adopt Rules of Procedure which determine the internal organization of the ECB and its decision-making bodies (Art. 12.3), approval of the ECB's annual accounts (Art. 26), recommend external auditors for the audit of both the ECB and national central banks (Art 27) and lay down the conditions of employment of staff (Art 36).

${ }^{113}$ The original Federal Reserve Act read that "the governor of the Federal Reserve Board, subject to its supervision, shall be the active executive officer". See Federal Reserve Act: Public Law 63-43, 63d Congress, H.R. 7837: An Act to Provide for the Establishment of Federal Reserve Banks, to Furnish an Elastic Currency, to Afford Means of Rediscounting Commercial Paper, to Establish a More Effective Supervision of Banking in the United States, and for Other Purposes, 1913.

114 The Federal Open Market Committee also plays a policy formulation role.
} 
mechanisms that, to cater for the specific nature of the common central bank, depart from best practices, but other legal mechanisms could seek to mitigate this problem.

117. A good example of this is the BEAC. The BEAC has an Oversight Board, labeled "Board of Directors" and composed of 14 directors. The BEAC's Charter does not prohibit Public Sector officials from siting on the Board, and most, if not all, directors are indeed such officials. This may seem a departure from the principle set out in para. 93. However, it is understandable that the member states seek a prominent and somewhat direct role in the oversight over their common central bank. Importantly the Charter of the BEAC includes important legal mechanisms that underpin the effectiveness of the Board's oversight role. Among those are (i) a detailed listing of the oversight responsibilities and decision-making powers (see Art. 32 and Box 1), (ii) a robust legal basis for the Audit Committee (Art. 64), and (iii) an additional external oversight mechanism (in the form of "censors:" see Art 62-63).

\section{CONCLUSIONS}

118. Well written central bank laws are critical to establish robust oversight within central banks. To provide strong legal underpinnings to this oversight, Legislatures need to adopt central bank laws that achieve the following four outcomes:

- $\quad$ Establish an Oversight Board... Central bank laws should systematically set up Oversight Boards, as these bodies are key to the good governance of central banks. Otherwise, oversight will directly be exercised by government, thus impeding on the central bank's autonomy.

- $\quad$...that is Well-Designed... Oversight Boards can take many forms and shapes, but good practices apply! One way is to design Oversight Boards as Supervisory Boards, composed of non-executive members only, and strictly focusing on oversight. Another way is to establish or strengthen a Board of Directors that combines executive and non-executive directors. Under such an approach, non-executive directors should have a sufficiently robust majority. Moreover, consideration could be given to appointing a non-executive chair, albeit with due regard to the role an executive chair can play when the Board is charged with public policy formulation. For both types of Boards, the number of Public Sector officials should be minimized, and care should be given to formulate as strong as possible eligibility criteria.

- $\quad$...with a Strong Oversight Mandate... Central bank laws should set out an explicit general responsibility of the Oversight Board to oversee executive management, in addition to explicit decision-making powers to (i) formulate the relevant internal organizational policies of the central bank and (ii) take specific oversight decisions.

- $\quad$...Buttressed by Strong Oversight Procedures! Procedural aspects should not be ignored, as they contribute to high quality decision-making. Specifically, the periodicity of meetings, the decision-making modalities (majority and quorum), and the right of 
initiative to call for meetings and table agenda items are critical procedural aspects of robust oversight. For Board of Directors, a quorum that requires a non-executive majority for oversight decisions would be a good practice.

119. Over and above these substantive legal aspects, from a formal legal perspective it is obvious that sufficient clarity and granularity in central bank laws are of utmost importance. 


\section{AnNeX I. Methodology OF ChARTS}

The initial analysis and research for the paper was prepared for, and presented at, the fifth HighLevel Forum on Central Bank Governance, titled Board Oversight and Legal Aspects, Financial Risk Management and Data Innovations (Dubai, 28-30 January 2019). This Forum was co-organized by the Finance and Legal Departments of the IMF and the Hawkamah Institute for Corporate Governance, based in Dubai. The audience of the Forum had a significant representation from Africa, Europe and the Middle East, including 10 governors and deputy governors, 18 central bank board members, and over 20 high-level officials from external auditors of central banks.

The authors initially put together a comparative analysis of the central bank laws of a 100 countries, focusing on 6 key legal governance metrics of central bank Oversights Boards. Specifically, the analysis covered:

1. whether or not central banks have an Oversight Board;

2. for those central banks with an Oversight Board, whether it takes the form of a Board of Directors or a Supervisory Board;

3. whether Oversight Boards were vested with monetary policy or not;

4. the number of non-executives on Oversight Boards;

5. the percentage of Public Sector officials on Oversight Boards, ${ }^{115}$ and

6. whether or not the chair of the Oversight Board is executive or non-executive.

Following the Forum, a decision was taken to transform the research into an IMF Working Paper. In that context, the authors widened both:

(i) the material scope of the analysis to include eligibility criteria of non-executive Board members; and

(ii) the geographical scope to include the entire IMF membership (except Nauru, Vanuatu and Palau). For some members, this includes more than 1 central bank per country (China, with the special administrative regions of Macao or Hong Kong). It also includes the national central banks of the ESCB as well as the ECB and the three other regional central banks (BCEAO, BEAC and ECCB). Some members do not have a central bank, e.g. Panama.

Overall, we have reviewed 174 central bank acts that were either contained in laws or treaties. We also reviewed banking acts and codes, civil codes, ordinances and decrees when they contained relevant provisions, as well as prevention of conflict of interest of public officials laws and corporate governance codes when they were applicable to central banks either on a voluntary or a mandatory basis. In some cases, we reviewed the constitutions as well as secondary legal sources (e.g. By-Laws, internal regulations issued by central banks or internal rules of procedure of Oversight Boards as well as Memoranda of Understanding between central banks an Ministries

${ }^{115}$ We only included government representatives with a vote. 
of Finance). Where the legal frameworks yielded uncertain results, we analysed the current composition of the Oversight Boards of the central banks as reported on their websites and annual reports. Where available, we also included information acquired during IMF missions.

Such legal frameworks are suceptible to amendments and so the statistical results presented in this Working Paper will most likely vary at a future point in time. The statistical data used for this paper is the one publicly available on May 1, 2019.

Here below is a one-country sample of the database:

\begin{tabular}{|c|c|c|c|c|c|c|c|c|}
\hline \multicolumn{9}{|c|}{ Country: Ukraine } \\
\hline \multicolumn{4}{|c|}{$\begin{array}{l}\text { Central Bank: } \\
\text { National Bank of Ukraine }\end{array}$} & \multicolumn{5}{|c|}{$\begin{array}{c}\text { Central Bank Act } \\
\text { Law of Ukraine On the National Bank of Ukraine }\end{array}$} \\
\hline \multicolumn{9}{|c|}{ Oversight Board } \\
\hline \multicolumn{9}{|c|}{$\begin{array}{c}\text { Yes: } \\
\text { Article } 8 \text { \& Article } 9 .\end{array}$} \\
\hline $\begin{array}{l}\text { Supervisory } \\
\text { Board (non- } \\
\text { executive) }\end{array}$ & \multicolumn{8}{|c|}{$\begin{array}{c}\text { Board of Directors } \\
\text { (executives \& non-executives) }\end{array}$} \\
\hline \multirow[t]{3}{*}{$\mathrm{N} / \mathrm{A}$} & \multicolumn{6}{|c|}{$\begin{array}{l}\text { Article } 10 . \\
\text { Constitution of the NBU Council }\end{array}$} & \multicolumn{2}{|c|}{ Chair of the Board } \\
\hline & \multicolumn{2}{|c|}{ Monetary Policy } & $\begin{array}{l}\text { No } \\
\text { Monetary } \\
\text { Policy }\end{array}$ & $\begin{array}{l}\text { \% government } \\
\text { representatives }\end{array}$ & \multicolumn{2}{|c|}{$\begin{array}{l}\% \text { non- } \\
\text { executives }\end{array}$} & $\begin{array}{l}\text { Executive/ } \\
\text { Governor }\end{array}$ & $\begin{array}{l}\text { Non- } \\
\text { executive }\end{array}$ \\
\hline & $\begin{array}{l}\text { Artic } \\
\text { Othe } \\
\text { Artic } \\
\text { Task } \\
\text { Cour } \\
\text { Artic } \\
\text { Pow } \\
\text { Cour } \\
\text { Artic } \\
\text { Func } \\
\text { NBU }\end{array}$ & $\begin{array}{l}7 . \\
\text { Functions 1) } \\
8 . \\
\text { of the NBU } \\
\text { cil } \\
9 \text {. } \\
\text { rs of the NBU } \\
\text { cil 1) 2) } \\
14 \text {. } \\
\text { ions of the } \\
\text { Board }\end{array}$ & $\mathrm{N} / \mathrm{A}$ & $\begin{array}{l}0 / 12 \\
0 \% \\
\text { Article } 10 . \\
\text { Constitution of } \\
\text { the NBU } \\
\text { Council } \\
\text { Article } 18 . \\
\text { Appointment } \\
\text { and Dismissal } \\
\text { of the NBU } \\
\text { Governor }\end{array}$ & $\begin{array}{l}11 / 12 \\
91.679 \\
\text { Article } \\
\text { Consti } \\
\text { the NE } \\
\text { Article } \\
\text { Functi } \\
\text { NBU B } \\
\text { Article } \\
\text { Duties } \\
\text { Autho } \\
\text { the NE } \\
\text { Gover }\end{array}$ & $\begin{array}{l}\text { ion of } \\
\text { Council } \\
\text { rd } \\
\text { es of the } \\
\text { es of }\end{array}$ & N/A & $\begin{array}{l}\text { Article } 12 . \\
\text { Chairman } \\
\text { and Deputy } \\
\text { Chairman of } \\
\text { the NBU } \\
\text { Council }\end{array}$ \\
\hline \multicolumn{9}{|c|}{ Eligibility Criteria for Non-executive Board Members } \\
\hline \multicolumn{2}{|c|}{ No or Irrelevant EC } & \multicolumn{2}{|c|}{ Weak EC } & \multicolumn{2}{|c|}{ Moderate EC } & \multicolumn{3}{|c|}{ Strong EC } \\
\hline \multicolumn{2}{|c|}{$\begin{array}{l}\text { This includes purely } \\
\text { representative } \\
\text { criteria }\end{array}$} & \multicolumn{2}{|c|}{$\begin{array}{l}\text { Focus on education } \\
\text { or } \\
\text { Some professional } \\
\text { experience }\end{array}$} & \multicolumn{2}{|c|}{$\begin{array}{l}\text { Focus on combined } \\
\text { education and minimum } \\
\text { professional experience }\end{array}$} & \multicolumn{3}{|c|}{$\begin{array}{l}\text { Focus on education and robust } \\
\text { minimum professional experience, } \\
\text { including in senior positions } \\
\text { May include rules to ensure diverse } \\
\text { skillset in oversight boards. }\end{array}$} \\
\hline \multicolumn{2}{|l|}{ N/A } & \multicolumn{2}{|c|}{ N/A } & \multicolumn{2}{|l|}{ Art. 10} & \multicolumn{3}{|c|}{$\mathrm{N} / \mathrm{A}$} \\
\hline
\end{tabular}


The database of current practices on governance of central banks is a practical tool as it has already been used for a forthcoming Departmental working paper by the IMF Middle East and Central Asia Department and IMF Legal Department's technical assistance to member countries.

We also used the database in the context of the innovation Lab's challenge that was launched during the 2019 Annual Meetings of the International Monetary Fund. We hosted a panel titled Promoting Good Governance in Central Banks: The Role of Non-Executive Directors. During the discussion available online at the following link the panelists directly asked the audience and, throught the website the broader civil society, to come with solutions to further enhance the efficacy of NEDs serving on Oversight Boards. 


\section{ANNEX II. Presidential vs Collegial Model of Executive Management in Central Banks}

\section{Presidential}

- The central bank is led by a single official (Governor, President, Chairman...) who is the Chief Executive Officer, tasked with the "dayto-day management of the affairs" of the central bank;

$\bullet$ The CEO is often assisted by executive ViceGovernors or Deputy-Governors (or "Gerentes", in the Latin-American model), appointed by him and/or the Board. Those deputies are under the CEO's authority; and

The CEO's tasks are typically coupled with powers of external representation, signature of currency and contracts, validation of minutes and documents, staff hiringpromotion, and internal rule-making.

\section{Collegial}

- $\quad$ The responsibility for executive management vests in an Executive Board directly;

- $\quad$ All Executive Board members are collegially responsible for the affairs of the central bank. The CEO presides over the Executive Board but has otherwise few (e.g., powers of external representation) other duties and responsibilities differing from those of the other Executive Board members;

The Executive Board may delegate specific executive tasks to individual Executive Board members; and

- In the purest form of the collegial model, the CEO may not even be listed among the decision-making bodies of the central bank.

\section{Number of Central Banks with Presidential vs. Collegial Executive Management}

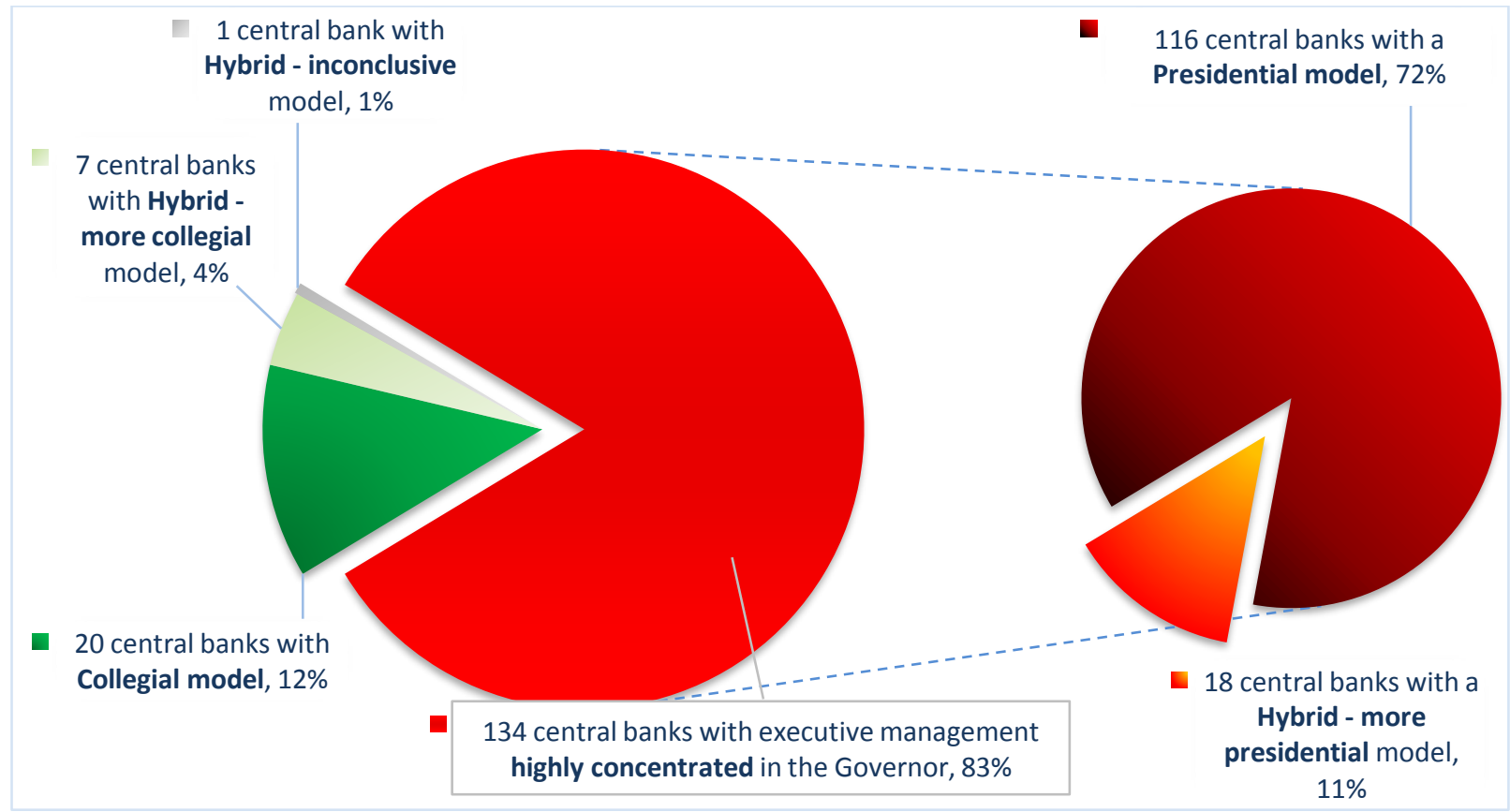

Source: IMF staff.

The data and definitions in this box are pulled from research by ECB counsel Panagiotis Papapaschalis while seconded to the IMF. 


\section{REFERENCES}

Abreu Faria, F., and Ermes Streit, R., 2016, Governance in central banks: a comparative study of the governance practices used by the central banks of Brazil, Canada and England.

Adams, R.B., and Ferreira, D.,2005, Theory of Friendly Boards.

Adams, R.B., and Mehran, H., 2011, Bank Board Structure and Performance: Evidence for Large Bank Holding Companies.

Amtenbrink, F., 2004, The Three Pillars of Central Bank Governance -Towards a Model Central bank Law or a Code of Good Governance.

Andersen, S., 2016, The Origins and Nature of Scandinavian central banking.

Arda, A., Gororo, M., Grochalska, J., and Mohlala, M., External Audit Arrangements at Central Banks, IMF, WP/18/199.

Athanassiou, P., 2014, Reflections on the Modalities for the Appointment of National Central Bank Governors.

Aufricht, H., 1961, Central Banking Legislation, International Monetary Fund.

Aufricht, H., 1965, Comparative Survey of Central Bank Law, International Monetary Fund.

Aufricht, H., 1967, Central Banking Legislation, Volume II, International Monetary Fund.

Bagehot, W., 1873, Lombard Street: a Desciption of the Money Market.

Berger, H., 2006, Optimal central bank design: Benchmarks for the ECB.

Berger, H., Lybek, T., and Nitsch, V., Central Bank Boards Around the World: Why Does Membership Size Differ? International Monetary Fund Working paper WP/06/281.

Bank for International Settlements, 2012, Core Principles for Effective Banking Supervision, Basel Committee on Banking Supervision.

Bank for International Settlements, 1963, Eight European Central Banks.

Bank for International Settlements, 2009, Issues in the Governance of Central Banks, Report from the Central Bank Governance Group.

Bank for International Settlements, 2015, Guidelines-Corporate Governance Principles for Banks, Basel Committee on Banking

Supervision.

Blinder, S. A., 2007, Monetary policy by committee: Why and How? 
Bossu, W., Hagan, S., and Weenink, H., 2017, Safeguarding Central Bank Autonomy: the role of transparency and accountability, in ECB Legal Conference-Shaping a New Legal Order for Europe: a tale of crisis and opportunities.

Capie, F., Goodhart C. and Schnadt N., 1994, The development of central banking.

Capie, F. and Wood, G., The Governance of Central Banks: With Some Examples and Some Implications for All, in the Oxford Handbook of the Economics of Central Banking.

Central Banking Directory, 2016 and 2019 editions.

Chamoun, E., and van Greuning, R., Effectiveness of Internal Audit and Oversight at Central Banks: Safeguards Findings, Trends and Observations, IMF, WP/18/125.

Colesa, Daniel, 2008, Naveen Boards: Does one size fit all?Conti-Brown, P., 2016, The power and independence of the Federal Reserve, Princeton University Press.Davie L. Paul, G., 2000, The Board of Directors: Composition, Structure, Duties and Powers, OECD.

Day, P, and Klein, R., 1987, Accountabilities: five public services.

Draghi, M., 26 July 2012, Speech at the Global Investment Conference in London.

Faleye, O., Hoitash, R., and Hoitash, U., 2013, "The Trouble with Too Much Board Oversight," MIT Sloan Management Review, Nr. 3p. 53-56.

Federal Reserve System, 2016, The Federal Reserve System: Purpose and Function.

Frisell, L. Roszbach, K. and Spagnolo, G., 2008, Governing the Governors: A Clinical Study of Central Banks, Sveriges Riksbank WP 221.

Friedman, M., 1962, Capitalism and Freedom.

Friedman, M., Schwartz, A., 1963, A Monetary History of the United States.

Galbraith, J. K., 19975, Money: Whence it Came, Where it Went.

González-Paramo, J., 2007, Expectations and credibility in modern central banking: A practitioner's view.

Organization for Economic Cooperation and Development, 2015, G20/OECD, Principles of Corporate Governance.

International Monetary Fund, 1999, Code of Good Practices on Transparency in Monetary and Financial Policies.

International Monetary Fund, 2018, Framework for Enhanced Engagement on Governance. 
International Monetary Fund, 2018, Global Financial Stability Report, A Decade after the Global Financial Crisis: Are We Safer?

International Monetary Fund, 2002, Safeguards Assessments-Review of Experience and Next Steps.

International Monetary Fund, 2015, Safeguards Assessments—Review of Experience.

International Monetary Fund, 2017, Safeguards Assessment-Update.

International Monetary Fund, 2019, World Economic Outlook Database.

Institute of Directors for Soutern Africa, 2015, Board size, General Guidance Note.

Irwin, N., 2014, The Alchemists.

Keynes, J. M., 1936, The General Theory of Employment, Interest and Money.

King III and IV, 2009 and 2016, Reports on Governance for South Africa.

Kirshner, J., 2007, Appeasing Bankers: Financial Caution on the Road to War, Princeton University Press.

Kraakman, R., Armour, J., Davies, P., Enriques, L., Hansmann, H., Hertig, G., Hopt, K., Kanda, H. (Author), Pargendler, M., Ringe, WG, Rock, E., 2017, The Anatomy of Corporate Law: A Comparative and Functional Approach, Oxford University Press.

Lastra, R., 2015, International Financial and Monetary Law (2 ${ }^{\text {nd }}$. Ed.).

Lipton, L. and Lorsch, J. A., 1992, Modest Proposal for Improved Corporate Governance.

Lublin, J., 2014, Smaller Boards Get Bigger Returns, The Wall Street Journal.

Lybek, T., and Morris, J., Central Bank Governance: A Survey of Boards and Management, IMF Working Paper WP/04/226.

Lybek, T., 2004, Central Bank Autonomy, Accountability, and Governance: Conceptual Framework.

Monteagudo, M., 2010, La independencia del Banco Central, BCRP; IEP, Universidad del Pacifico.

Nathan, A. and Groman, D., 2019, Central Bank Independence, Goldman Sachs Top of Mind.

Organization for Economic Cooperation and Development, 2017, Corporate Governance Factbook.

Quinn, S. and Roberds, W., 2006, An Economic Explanation of the Early Bank of Amsterdam, Debasement, Bills of Exchange, and the Emergence of the First Central Bank, Federal Reserve Bank of Atlanta.

Roberds, W. and Velde, F., 2014, Early Public Banks, Federal Reserve bank of Chicago. 
Russo, C., Lastra, R., M. and Blair W., 2019, Research Handbook on Law and Ethics in Banking and Finance.

Sibert, A., 2006, Central Banking by Committee.

Tuladhar, A., Governance structures and Decision-Making Roles in Inflation Targeting Central Banks, IMF Working Paper WP/05/183.

Siklos, P., 2002, The Changing Face of Central Banking, Cambridge University Press.

Sullivan, K, Camilleri, M., and Lybek, T., Audit Committees in Central Banks, IMF Working Paper WP/07/73.

Ugolini, S., 2017, The Evolution of Central Banking: Theory and History, Palgrave Studies in Economic History.

United Kingdom, 2018, Corporate Governance Code.

World Bank, 2011, Bank Regulation and Supervision Survey.

Yeager, L., 1962, In Search of a Monetary Constitution, Harvard University Press.

Yermack, D., 1996, Higher Market Valuation of Companies with a Small Board of Directors, Journal of Financial Economics. 